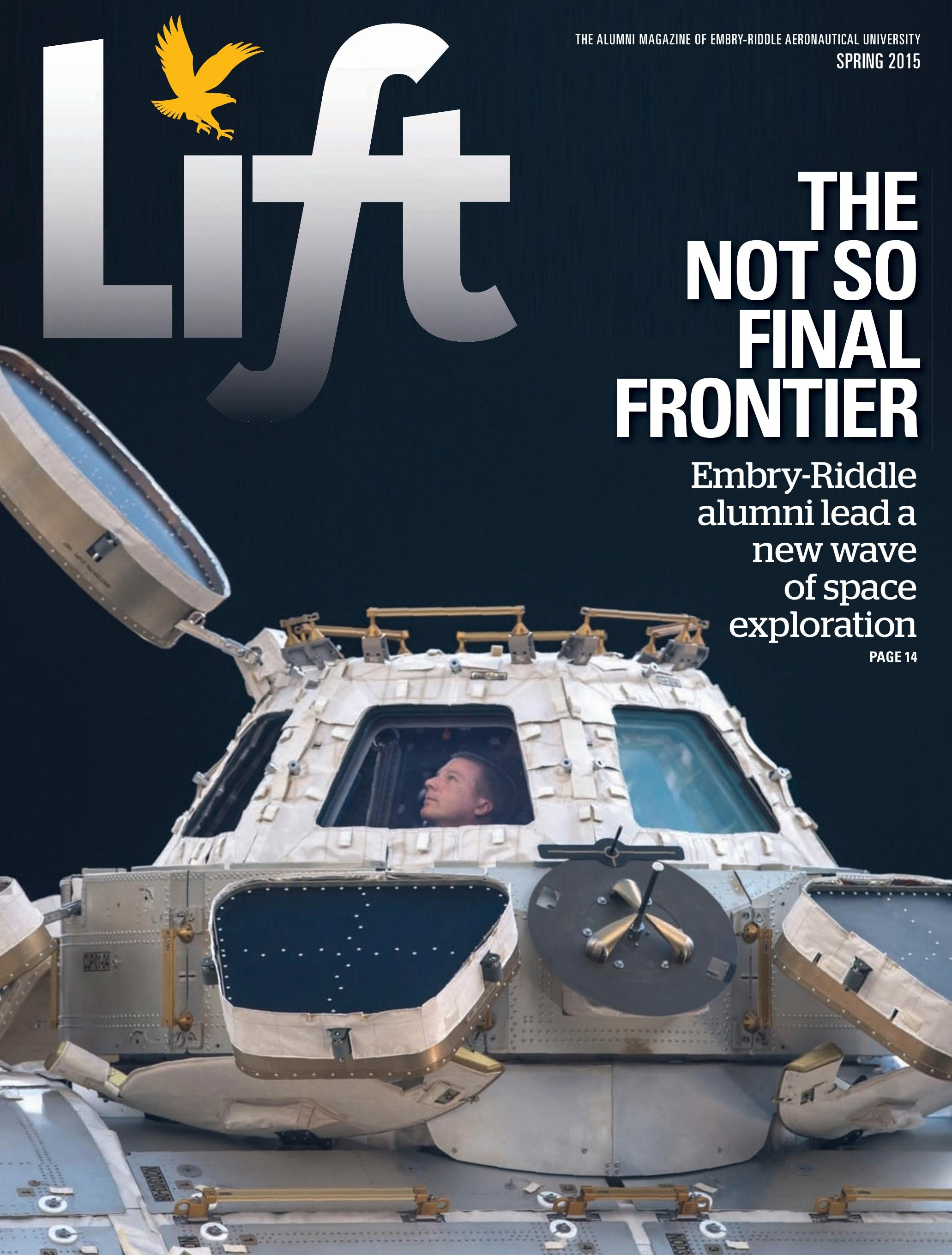




\section{FROM THE PRESIDENT}

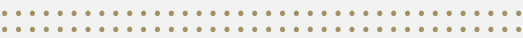

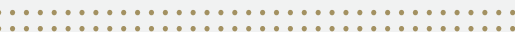

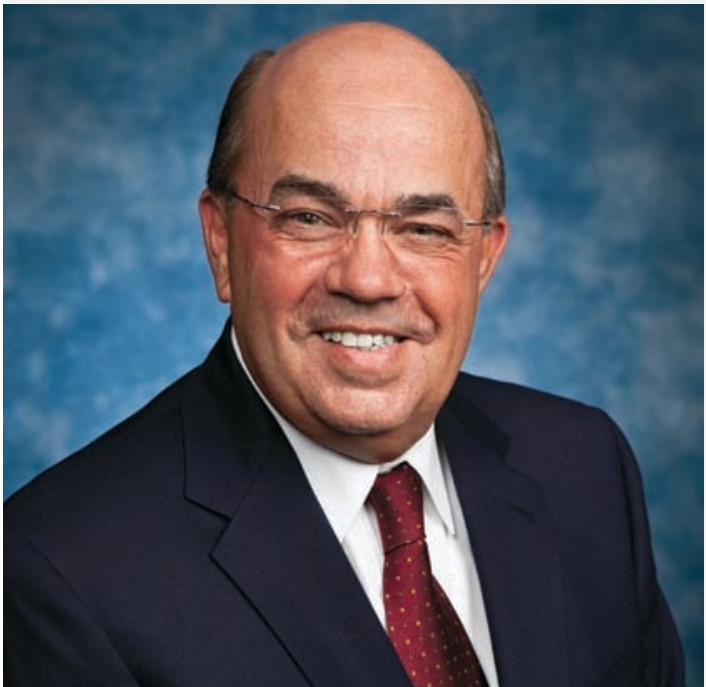

Fifty years ago this April, Embry-Riddle made its historic move from Miami to Daytona Beach, taking a giant and uncharted step forward in its mission to become the world's leader in aviation and aerospace education.

That mission, I think it's safe to say, has been an unqualified success.

But the hard-earned leadership position we enjoy today is not a state of being; it is a way of life. Embry-Riddle has never been content to sit still. While today's Embry-Riddle is the product of a vision begun long ago, tomorrow's Embry-Riddle will be a product of our vision today.

And our vision is as ambitious as ever, with our next great step already in motion.

Today, Embry-Riddle is on its way to becoming an entrepreneurial universitya research-intensive institution of higher education that is dedicated to the pursuit and creation of new knowledge for commercial applications.

It is an ambitious vision, but we are already making great progress. On every front-faculty, students, facilities, technology and programs-we are investing in expanding our capabilities. In just a few short years, we have:

- Added Ph.D. programs in our key areas of excellence, achieving a Level VI classification, will mark a new the highest level available, from the Southern Association of Colleges and Schools Commission on Colleges;

- Recruited more top faculty than ever before to conduct leading research;

- Provided key services to help faculty manage intellectual property and commercialization opportunities, resulting in significant increases in patent applications;

- Adopted enrollment strategies that have increased the number and quality of our students to unprecedented levels;

- Secured vital funding for the development of a wind tunnel at our Aerospace Research and Technology Park;

- Constructed new facilities at our Daytona Beach and Prescott campuses, with more to come, to advance our research capabilities, accommodate our growth and enhance the student experience.

With these investments in talent, resources and partnership opportunities, I am confident that today's Embry-Riddle will achieve a global reputation as the entrepreneurial university of aviation and aerospace.

I believe that this is a time of great transformation at Embry-Riddle-the beginning of something very special. Much like those who moved EmbryRiddle from Miami to Daytona Beach 50 years ago, the course we are on now

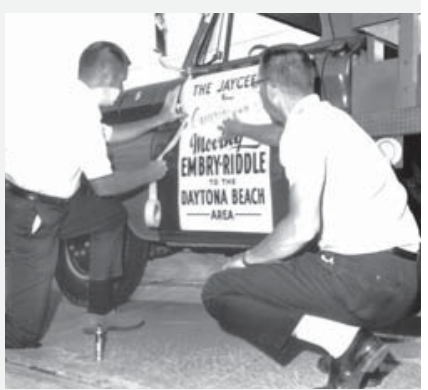
era of achievement for our great university.

My best,

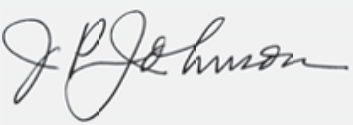

John P. Johnson, Ph.D. PRESIDENT AND CEO
Volume 11, No. 1

Lift, the alumni magazine of Embry-Riddle Aeronautical University, is published twice annually (spring and fall).

Copyright () 2015

Embry-Riddle Aeronautical University

Florida/Arizona/Worldwide

600 S. Clyde Morris Blvd.

Daytona Beach, FL 3211

All rights reserved

Senior Vice President of External Relations and Chief Marketing Officer Bill Hampton ('98, '00, DB)

Senior Executive Director of Development Christopher Lambert, J.D.

Executive Director of Alumni Relations Bill Thompson ('87, PC)

Senior Editorial Director

Anthony Brown

Editor

Sara Withrow

Communications Specialists

Melanie Stawicki Azam

Alan Marcos Pinto Cesa

\section{CONTRIBUTORS}

Andreia Brown ('15, DB)

Yoon Choi, Director of Annual Giving Bob Coope

Keith Deaton ('05, '12, DB), Director of

Alumni Relations

Lauren Eggert, Art Director

Molly Justice, Director of Communications, Embry-Riddle Worldwide

Jason Kadah, Communications Manager Paula Kropp, Database Manage Daryl LaBello, Multimedia Producer David Massey, Multimedia Producer Kevin Montgomery, University Archivist Edmund Odartey ('04, '10, DB), Director of Alumni Relations, Daytona Beach

Capt. Brian Schiff ('93, WW)

Published by McMURRY/TMG, LLC

Senior Content Editor

Tom Weede

Creative Director

Ed Mann

Senior Art Director

Tamara Kopper

Production Manager

Shannon Cross

Production Technology Specialist

Sonia Fitzgerald

Account Manager

Mary Jane Sweetland

Embry-Riddle Aeronautical University is an Affirmative Action/Equal Opportunity Employer and does not discriminate on the basis of race, color, religion, gende age, national origin, handicap, veteran's status or sexual orientation.

Nonprofit identification: 59-0936101.

Change address, unsubscribe or email the editor at liftmag@erau.edu.

8 Printed on recycled paper 

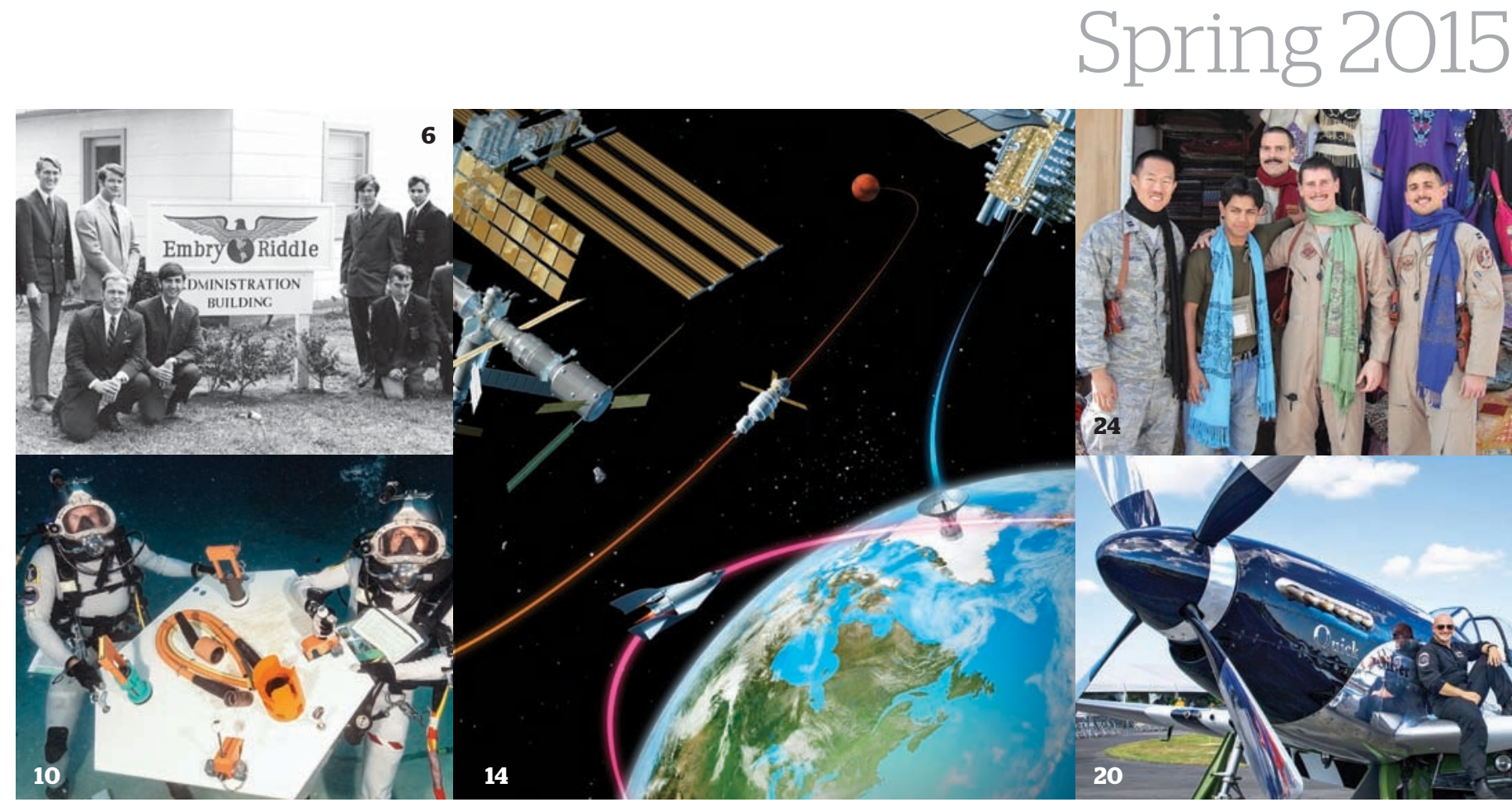

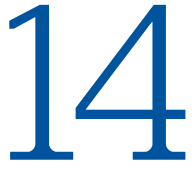

All

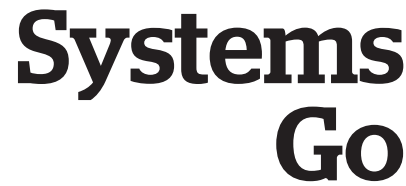

Embry-Riddle alumni play key roles in space exploration and the growing solar system economy

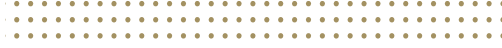

IN OTHER WORDS

5 Pilot Perspective

Capt. Brian Schiff ('93, WW) explains why pilots shouldn't over-rely on the autopilot

WINGS OF LEGACY

6 Veteran Roots Run Deep

At the height of the Vietnam War, service members found a haven at Embry-Riddle during turbulent '60s, '70s and beyond

\section{FLIGHT PATH}

\section{Love at First Flight}

Bill Borgsmiller ('97, PC) lives, breathes, works and plays aviation, and always has-and it all started by happenstance

\section{Finding NEEMO}

Embry-Riddle teams up with NASA to conduct research at the world's only undersea laboratory
ALUMNI @WORK

\section{On Stage in the Air} Scott "Scooter" Yoak ('08, DB) is living a pilot's dream; he flies a North American P-15 Mustang for a living

GIVING TO EMBRY-RIDDLE

\section{Giving a Lift to Future Pilots}

Citation Jet Pilots Owner-Pilot Association and the Bob Hoover Legacy Foundation award scholarships for flight students

\section{ALUMNI IN ACTION}

\section{Changing Lives, One Scarf at a Time}

An alumnus' efforts to benefit Afghan widows and their families

\section{Chatter}

News and notes

from the world of

Embry-Riddle

\section{Feedback}

Embry-Riddle

alumni and friends

offer comments

and opinions
26 Alumni News

A message from the

Alumni Association, upcoming events and more
32 Class Notes

Find out what

your fellow

alumni are up

to now

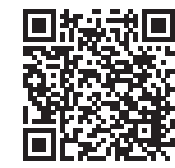

READ

LIFT ONLINE!

ON THE COVER: NASA astronaut U.S. Air Force Col. Terry Virts ('97, WW) gazes at Earth from inside the Cupola, the observatory module of the International Space Station (ISS). Virts is serving a five-and-a-half month mission aboard the ISS. He returns to Earth in May. 


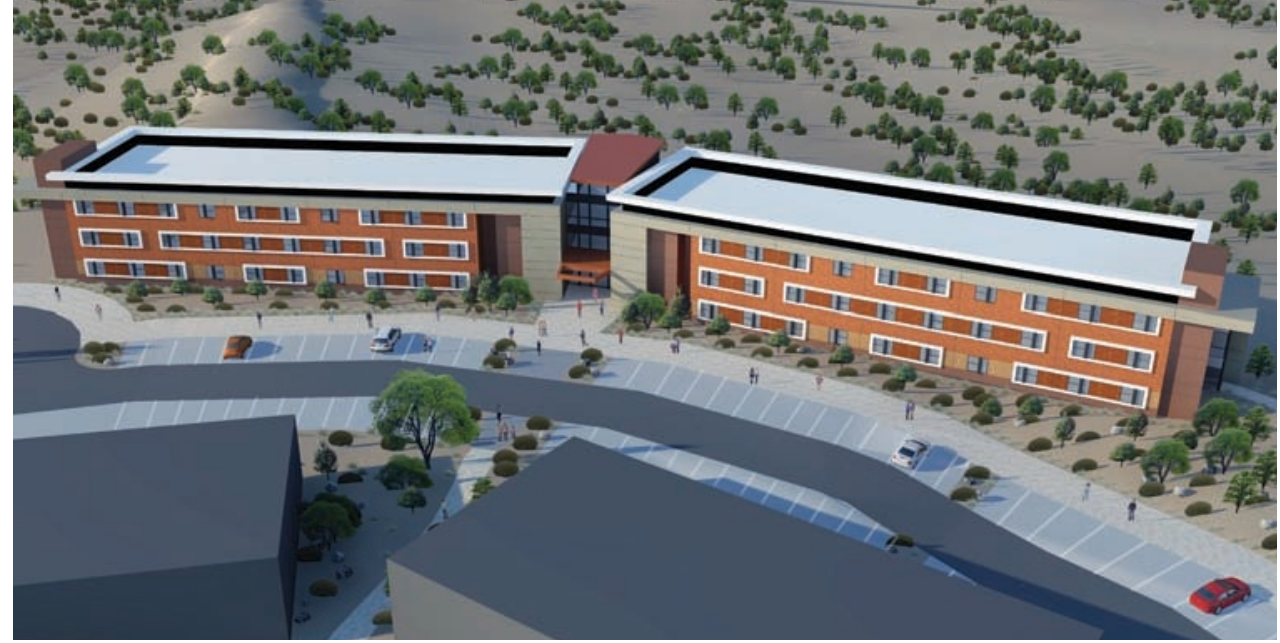

\section{ALTIMETER: \\ HIGH POINTS AT \\ EMBRY-RIDDLE}

AffordableCollegeOnline.org named the Prescott Campus among its "Million Dollar ROI" (Return on Investment) ranking.

\section{Scholar-athlete Andrea}

Froshaug, a junior at the Daytona Beach Campus, was honored as the Women's Soccer National Player of the Year by the NAIA and the National Soccer Coaches Association of America.

The Prescott Campus's soccer programs produced 12 NAIA Scholar-Athletes, men and women players who earned a $3.5 \mathrm{GPA}$ or higher.

\section{The Southern Association} of Colleges and Schools Commission on Colleges awarded Embry-Riddle its highest level of accreditation, Level VI: Institutions that Offer Four or More Doctorates.

\section{Embry-Riddle's Worldwide} Campus online bachelor's degree programs were ranked No. 5 for the second consecutive year by U.S. News \& World Report.

\section{U.S. News \& World Report named Embry-Riddle's} undergraduate Aerospace Engineering program No. 1 (DB) and No. 3 (PC). The Daytona Beach Campus was also named Best Southern University for veterans and active service members.

Embry-Riddle is now the only university in the nation to offer a complete slate of Human Factors degrees: B.S., M.S. and Ph.D.

\section{Growing Gains}

\section{Prescott Campus expands housing capacity to accommodate growth}

W

ith occupancy rates hovering at 104 percent for the past two years, the Prescott Campus is in dire need of more on-campus housing for its growing student population. A new 66-unit, three-story residence hall, which broke ground in January, will help fill this need.

"We currently have 865 available beds. This accounts for no single rooms, which is a high demand and, I would argue, a growing trend in higher education," says Jason Langston, director of housing and residence life at the Prescott Campus. Adding to this trend is an overall growth in student population. Fall 2014 marked the largest ever incoming class of freshmen at the Prescott Campus and a record number of students overall. As of August 2014, the campus boasted 2,035 students, an increase of nearly 10 percent compared with fall 2013.

The new residence hall, which is expected to be complete in December and open for business as of January 2016, will add 264 beds, bringing the total on-campus housing complement to 1,123. The 66,191-square-foot coed facility will accommodate four students per unit. "Each suite will have the capacity to accommodate up to six students in an overbooked situation," says Chris Hardesty, Embry-Riddle's director of planning and construction management.

The estimated \$15 million facility will include a small fitness center, a self-use laundromat, vending areas, a conference and meeting room, and an exterior patio, Hardesty adds.

"The last residence halls built at Prescott were the Thumb Butte Complex, a series of four modular buildings that house 120 students," Langston says. They were completed in 2002 . "We eagerly anticipate the completion of this new facility," he adds. "I know that our students are excited about the increased housing availability it will provide." -Sara Withrow

\section{Embry-Riddle and Flight Research to Develop Aircraft Training Programs}

The Robertson Safety Institute at EmbryRiddle's Prescott Campus and Flight Research Inc. have united to produce world-class training and curriculum programs for aircraft loss-of-control situations.

The agreement couples the extensive aviation knowledge of the world's largest aerospace university with the handson approach to loss-of-control recovery experience provided by the Mojave, Calif.-based corporation.

"Partnering with Flight Research is part of our commitment as a university to understand the science of aviation safety, ensure our students receive the best training in the world, and share our knowledge with all aviators," says Erin Bowen, who chairs the Prescott Campus Safety Science department, which includes the Robertson Safety Institute. -Jason Kadah

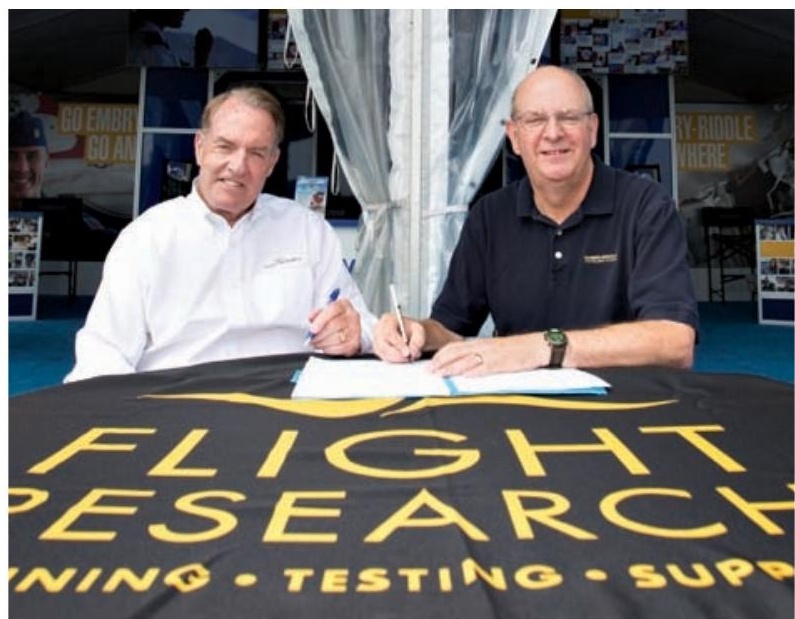

William C. Korner, chairman and CEO of Flight Research Inc., left, and Frank Ayers, chancellor of Embry-Riddle Prescott Campus. 
It may look like the latest version of Call of Duty, but it's not a game. It's an assignment in ASCl 615 Aviation/Aerospace Accident Investigation and Analysis at Embry-Riddle's Worldwide Campus.

"The virtual crash lab provides a unique, stimulating and enjoyable environment for students to practice accident investigation techniques and for faculty to evaluate students on their understanding and application of investigative technologies," says Associate Professor Katherine Moran.

Graduate students inspect plane crash

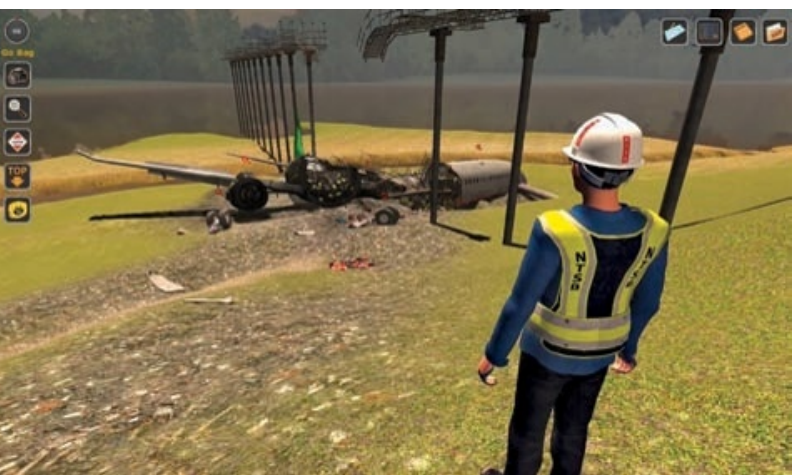
scenes and collect data-all from the comfort of their home, office or classroom. Much like a video game, students only advance once they've successfully mastered certain tasks.

Launched in May 2014, the virtual crash lab first introduces students to an animated crash using a short video. Students then choose a male or female avatar to be the National Transportation Safety Board investigator who walks through the crash site.

Watch the virtual crash investigation trailer: http://bit.ly/1IstITJ -Molly Justice

\section{Supplying the Demand for UAS Operators}

\section{Graduates find ready job market in states and abroad}

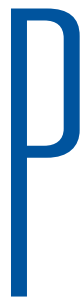

ilots and operators for unmanned aircraft systems (UAS) are in high demand, says Dan Macchiarella, professor and chair of the Aeronautical Science department at Embry-Riddle's Daytona Beach Campus. If and when the FAA publishes regulations for commercial use of UAS, the need for operators is likely to grow beyond the current strained supply.

"With the changes in the global war on terror, the U.S. government is contracting companies to train their pilots and/or to go on government missions. That's where many of our graduates go," Macchiarella says.

One hundred percent of the program's graduates are employed within one year, he adds. They find jobs with government agencies in the United States, as well as agencies in countries that allow commercial use of UAS. Enrollment has ballooned from 11 students, when the program began in 2011, to more than 200 in the fall of 2014. Embry-Riddle now touts the largest collegiate UAS program in the country.

Students enrolled in the UAS degree program study engineering and robotics, as well as operating, maintaining and programming small and medium-sized UAS. Graduates can work as UAS operators, as well as sensor technicians, mission planners and communications support personnel.

The Advanced Flight Simulation Center at the Daytona Beach Campus includes multiple simulator stations with controls similar to a Predator or Reaper-class aircraft. Embry-Riddle's program focuses on commercial uses for UAS,

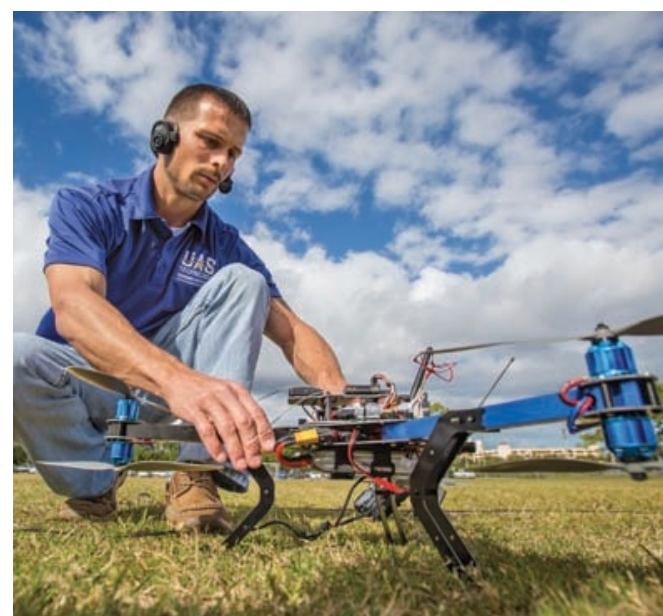

\section{UAS UNIVERSITY}

Read more about how Embry-Riddle is shaping the unmanned aircraft systems industry: alumni.erau.edu/UASResource

but due to national security interests regulating the technology, the degree program is only available to U.S. citizens. to complete the program. But that may change soon, Macchiarella says. "If the FAA rules that operating a UAS requires some level of pilot certification, we'll probably require that level from our graduates. But right now, both groups of students are getting hired." erau.edu/degrees/ unmanned-aircraft-systems-science -Alan Marcos Pinto Cesar
Currently, a pilot's license is not required
Daytona Beach Campus Women's Soccer Coach Samantha Bohon was inducted into the Seabreeze High School Hall of Fame. In 2014, Bohon led Embry-Riddle to its eighth consecutive NAIA national tournament appearance.

University Business magazine recognized Embry-Riddle as a Model of Efficiency for streamlining operations through technology.

\section{Allianz Global Corporate \&} Specialty recognized Daytona Beach Campus faculty and students for compiling and analyzing 60 years of aviation safety reports for its Global Aviation Safety Study. http://bit.ly/1z6XaNj.

BY THE NUMBERS

\section{Degrees of Interest}

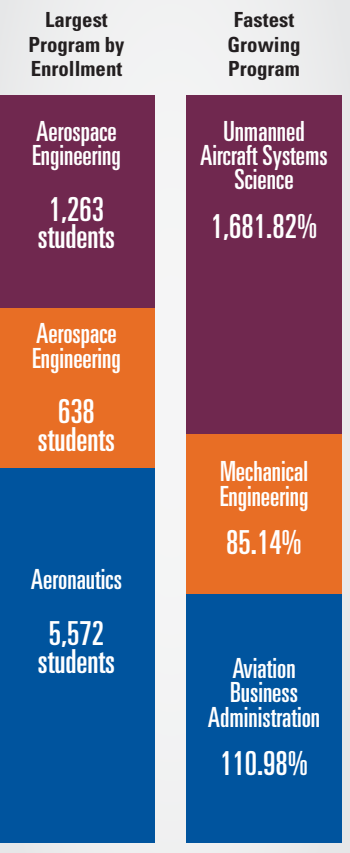

Daytona Beach Campus

Prescott Campus

Worldwide Campus

NOTES: "Fastest growing" is based on four-year rate of growth; it does not include programs with an four years of data. All data reflects fal enrollment trends through 2014.

SOURCE: ERAU Office of Institutional Research 


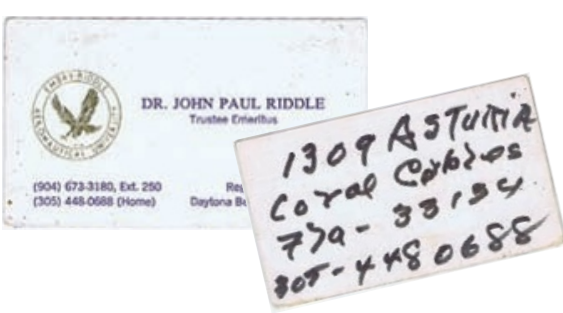

icon of aviation history. I carry it in my wallet to this day. Do note which direction the "Eagle" is flying on the card!

Barry Cohen ('79, '80, DB)

A.S. Aviation Management;

B.S. Aeronautical Science; MBA-Aviation based on a topic explored in the fall 2014 edition: unmanned aircraft systems. Held Sept. 18, 2014, at the Daytona Beach Campus, the inaugural Lift, Off the Page round-table event featured faculty/alumni subject matter experts, who examined the challenges and opportunities surrounding the emerging UAS industry. Prescott Campus students

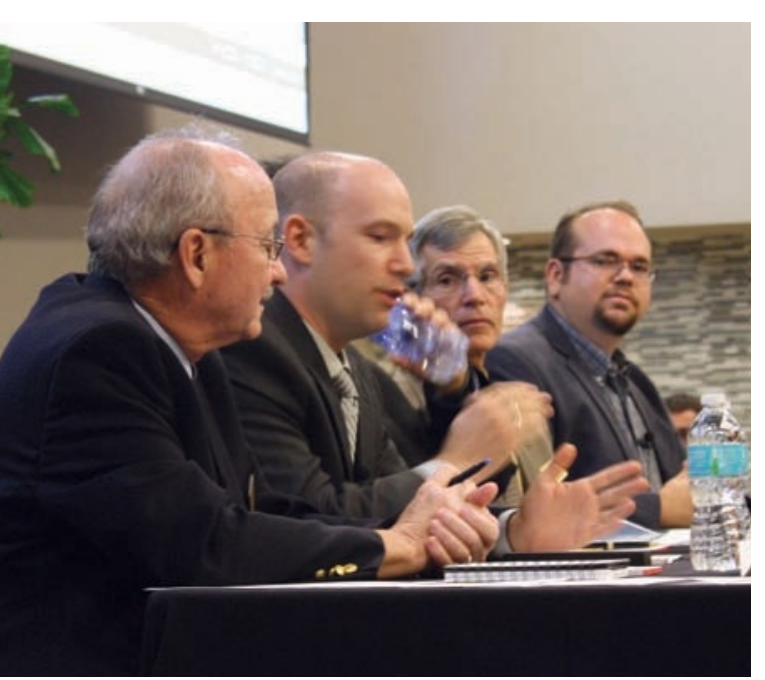

watched simultaneously at a viewing party there, and alumni tuned in online to the livestream presentation. Missed it? Watch Lift, Off the Page here: http://youtu.be/ Fmc0bkRrb4w. We're planning another Lift, Off the Page for this fall. Let us know what you think:

\section{liftmag@erau.edu.}

\section{-SARA WITHROW, EDITOR}

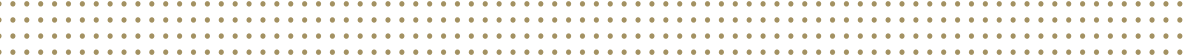

Plaudits for Lift, Off the Page

I cannot thank you enough for providing me with the link to the videotape of the Lift, Off the Page panel discussion [Sept. 18, 2014], which allowed me to gain tremendous knowledge on unmanned aircraft systems (UAS). The participants were full of skills and experience. I can assure you that students have gained great insight on UAS applications and future usage. Your presentation is proof of the reasons why our university will always be the BEST nationwide. Again, thank you.

Eugene Siewe ('08, ‘12, WW) A.S. Professional Aeronautics; B.S. Professional Aeronautics

\section{ERAU Aviation Icon}

I met the late John Paul Riddle, one of Embry-Riddle's founders, while I was a freshman studying aeronautical science in September 1975. Later, as an airline pilot, I met Mr. Riddle again in Seattle, Wash., around $1985-86$ at an alumni get-together. It was here that he gave me his card with his Miami home information on the reverse side. The Miami connection was that the parents of my wife, Julie (then my girlfriend), lived in Miami. Mr. Riddle said, "Anytime you are in Miami, you two come over for a visit." Meeting the man on these two occasions was incredible. To me, the card with Mr. Riddle's note is a priceless

\section{Article Sparks Memories}

Thank you for sending me the copy of Lift magazine, which contained a picture of Royal Air Force cadets on parade at Riddle Field during World War II [Wings of Legacy, fall 2014]. It is possible that I was in this group. I did my flying training there early in 1945 and will never forget the hospitality of the kind people of Clewiston and West Palm Beach, led by Mrs. Ira Nesmith. I have been back many times with my wife (whose engagement ring I bought in Miami).

My thanks to you for reviving those memories.

Peter Brannan ('45, BFTS, Non-degree) No. 5 British Flying Training School (Course 25)

EDITOR'S NOTE: The picture to which you refer, Peter, actually depicts Embry-Riddle's Carlstrom Field in Arcadia, Fla., where Royal Air Force (RAF) cadets were trained from 1941-42. Thereafter, $R A F$ training was moved to Riddle Field in Clewiston, Fla.

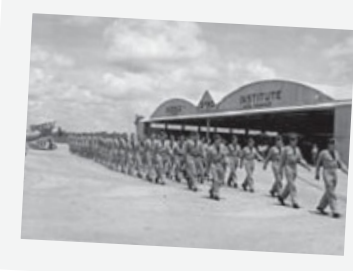

TALK TO US

We invite your feedback on Lift content or topics related to the university. Letters may be edited for style, length and clarity. Submission does not guarantee publication.

EMAIL: liftmag@erau.edu

WRITE: Lift Editor ERAU Alumni Relations 600 S. Clyde Morris Blvd. Daytona Beach, FL 32114 


\section{Pilot Perspective: Automation Is a Tool Not a Crutch}

\section{BY CAPT. BRIAN SCHIFF $(' 93$, WW}

Aviation safety is improving, but advances in automation are creating another danger-automation dependency. In the last half-decade, several airline accidents have been attributed in part to a pilot's overreliance on the autopilot and other automated systems. These include Colgan Flight 3407 (2009); Air France Flight 447 (2009); Asiana Flight 214 (2013); and UPS

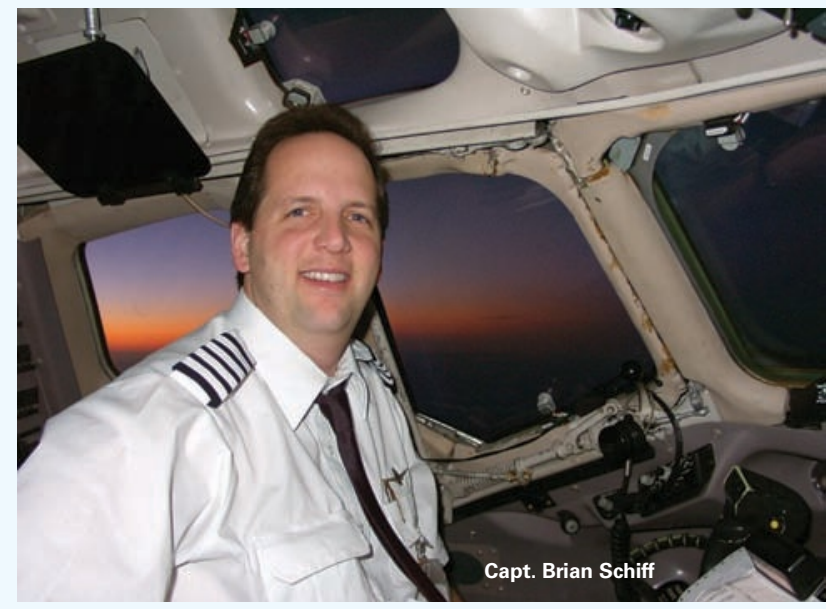

Flight 1354 (2013), to name a few. Additionally, automation dependency has been indicated in an increasing number of general aviation accidents. Modern autopilots have become so reliable that they have lulled us into a sense of complacency. For the sake of safety, pilots must view the autopilot as a tool to be utilized, not a crutch.

When I began learning to fly (and, I am still learning), autopilots were so unreliable that we habitually kept a close eye on them. Even if an autopilot had a heading-hold mode, it was only regarded as a "wing-leveler," enabling a pilot to look away for just a moment or two. The Boeing 727's autopilot could be engaged in either pitch or roll mode, or both. We often would disconnect only the pitch mode to manually make changes, like leveling off or beginning a descent. This was because hand-flying was smoother than the autopilot. Also, the 727's antiquated autopilot could not be relied upon to level off at the preselected altitude. Some didn't even have altitude-capture capability.

Today's autopilots are far more advanced. They rival and exceed the smooth flying of skilled pilots, so the pervasive tendency is to use them more. Excessive use of aircraft automation can, however, lead to complacency and the erosion of basic flying skills.

For example, while my new-hire co-pilot was flying the MD-80, I made the required callout 1,000 feet prior to the target level-off altitude. He acknowledged the "one-to-go" call, but before reaching the assigned altitude, he leaned down to retrieve something from his kit-bag. He remained "heads-down" throughout the level-off, completely trusting that the autopilot would dutifully perform as programmed. He hadn't developed the healthy dis trust for automation that I had. I watched this display of automation dependency with dismay. The autopilot did its job, but he never looked up to confirm it. To teach him not to do this, I tweaked the altitude alerter when he wasn't looking. This sounded a warning that we had "busted" our altitude. His flinch and the adrenaline rush that no doubt followed would hopefully help him remember this lesson.

There are two fundamental reasons for autopilot mishaps. Either the autopilot doesn't respond as programmed, or it dutifully obeys an erroneous command. Safety is dramatically increased if both of these factors are vigilantly monitored and kept in check.

Despite the advancements in technology, there are still occasions when manual control trumps cockpit automation. For example, using the autopilot during a visual approach can often cause an unstabilized descent, a leading cause of airplane accidents. Especially from a downwind leg, executing a visual approach with the autopilot can be more complex than clicking it off and simply flying the airplane manually.

A pilot's prime directive is to fly the airplane safely. This means that he or she should be skilled in operating at all levels of automation, including the lowest level-flying by hand. I suggest that all pilots maintain their flying proficiency by giving the automation a break and flying the airplane by hand regularly.

There is no substitute for a well-trained and proficient pilot. The autopilot's engage switch should not be a pilot's disengage switch.

EDITOR'S NOTE: Schiff earned a Bachelor of Science in Professional Aeronautics from Embry-Riddle. He is an MD-80 captain for a legacy airline and a part-time flight instructor.

SEND US YOUR STORY In Other Words gives you the opportunity to share your industry-related or personal perspective with Lift readers. Email submissions/proposals to liftmag@erau.edu. 

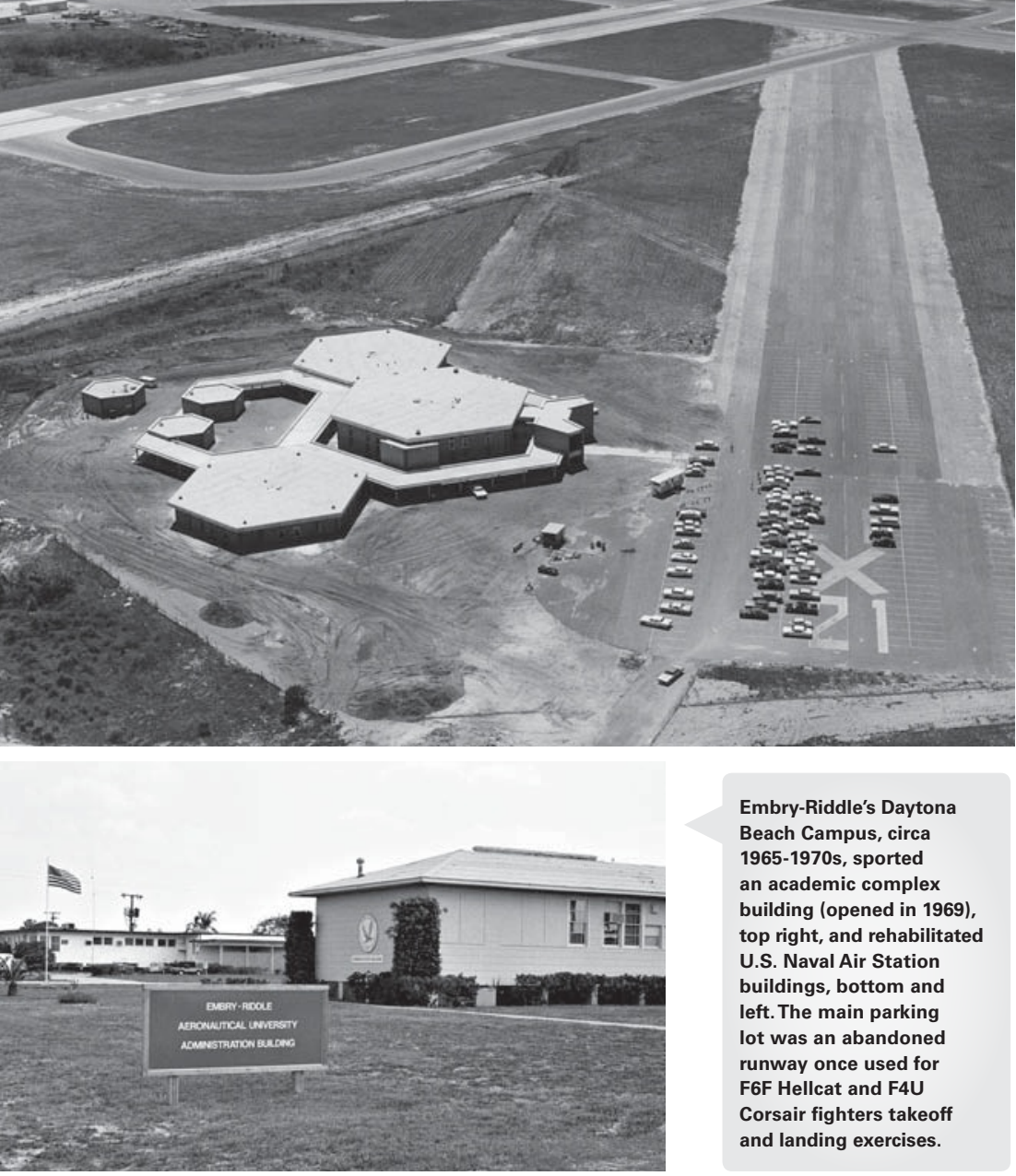
Beach Campus, circa 1965-1970s, sported an academic complex building (opened in 1969) top right, and rehabilitated U.S. Naval Air Station buildings, bottom and eft. The main parking lot was an abandoned runway once used for F6F Hellcat and F4U Corsair fighters takeoff and landing exercises.
Not everyone believed in the war, especially in 1970, at the height of it," she says.

\section{Economic Driver}

The influx of veterans proved an economic positive for Embry-Riddle, which was struggling financially in the early 1970s. Longtime professor Jim Cunningham, now retired, recalls President Hunt coming to the faculty in 1971 and asking for a personal loan so the university could make payroll. Hunt went without a paycheck for up to two years, and faculty salaries were frozen for three, Cunningham says.

Recruiters actively pursued veterans to boost the balance sheets, because those tuition dollars were guaranteed by the GI Bill. Embry-Riddle offered veterans a head start on their education through course equivalency exams and credits given for flight credentials and maintenance experience.

By 1974, approximately 50 percent of the university's 205 graduates were veterans, says Ladesic, who returned to Embry-Riddle to teach in the 1970s and is today associate dean of industry relations and outreach for the College of Engineering. "There's no doubt in my mind that the appeal Embry-Riddle had, and still has to the GI, was to the mutual benefit of them and the university."
40 YEARS OF ROTC

By the Numbers 1972

Founding year of Embry-Riddle's ROTC program with the installation of Air Force Det. 157 at the Daytona Beach Campus.

Today, Air Force, Army, Navy and Marine Corps ROTC programs are offered at the Daytona Beach Campus; and Air Force and Army detachments are located at Embry-Riddle's Prescott Campus in Arizona.

\section{$3,000+$}

Number of

commissioned officers since 1972 collectively produced by EmbryRiddle's ROTC programs.

$1,600+$

Number of officers commissioned through Det. 157.

Source: Embry-Riddle ROTC
Colgan says. "We never would have treated veter ans coming home in the way that kids did at other schools." But that didn't mean that all of the students supported the war. "Although we were not a campus that was demonstrating, calling veterans names and burning flags or administration buildings, there was an active discussion going on about the Vietnam Conflict.

\section{MYSTERY HISTORY CONTEST}

Name an

Embry-Riddle alumnus who is a flying ace.

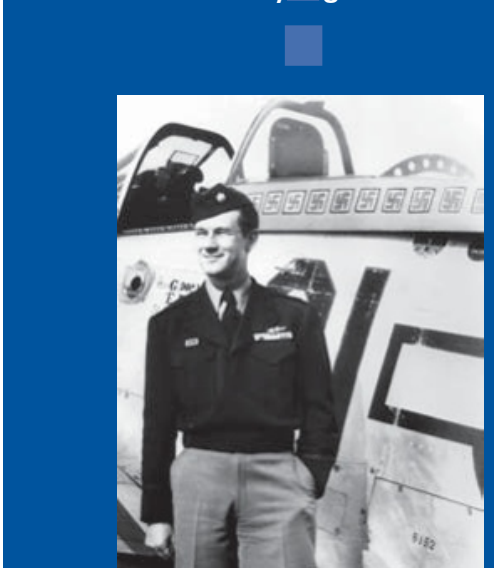

\section{Are you an Embry-Riddle history buff?}

Then here's your chance to show us your stuff! Enter our Mystery History Contest for a chance to win a copy of Forever an Eagle, a pictorial history of Embry-Riddle Aeronautical University.

TO WIN: Search the University Archives online (www.erau.edu/about/archives) for the correct answer. Send your response to the email address on the archives webpage and your name will be entered into a random drawing held after May 15.

Tim Glover ('80, DB) of Florida is the winner of the fall 2014 Mystery History Contest. Glover correctly identified the first name of Embry-Riddle's co-founder (T. Higbee Embry): Talton.

Embry-Riddle's Archives department is dedicated to preserving the memories and artifacts belonging to the university's rich history. 


\section{FLIGHT PATH}

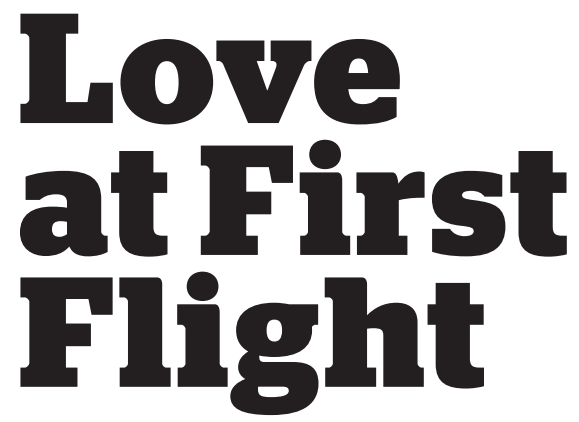

Bill Borgsmiller ('97, PC) lives, breathes, works and plays aviation-and always has

BY BOB COOPER

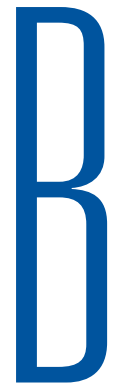

ill Borgsmiller ('97, PC)

is a young president

and CEO whose

air-services firm will

soon add its 100 th

employee-but as

young Billy in Red

Bluff, Calif., he was just a kid who loved flying.

Strike that: he still is. "The joke in my house,"

he says, "is that my passion is flying, my

hobby is flying and my other wife is flying."

When he talks about his lifelong love affair with aviation you soon realize that an early start always kept him several steps ahead. First flight in a small plane at age 4. First flight instruction at 7. First part-time aviation job at 12. First solo flight at 16. Graduation from Embry-Riddle's Prescott Campus with a Bachelor of Science in Aeronautical Science after a mere two years, four months. And now, at 38, he's one of America's youngest CEOs of a homegrown aviation company.

By the time he entered Embry-Riddle, Borgsmiller had earned nearly a year's worth of college credits as a high school senior attending Embry-Riddle's Worldwide Campus at McClellan Air Force Base near Sacramento-a five-hour round-trip drive in his old Jeep pickup twice a week. He'd also already earned a commercial pilot's license with 750 hours of flight time before arriving in Prescott, and knew many planes inside and out. And it all started by happenstance.

\section{Teenage Grease Monkey}

"My dad is an orthopedist and one day a kid came in with a broken elbow, caused by a propeller kicking back when he was rotating it. He agreed to fix the arm for free if that kid's dad would hire me at the airport, because he knew I was in love with airplanes." Thus began the unlikely partnership between Mike Rust, who owned a small charter and repair operation, and the airport kid, who spent a big chunk of his adolescence from ages 12 to 18 fueling and fixing aircraft, and traveling with Rust in 


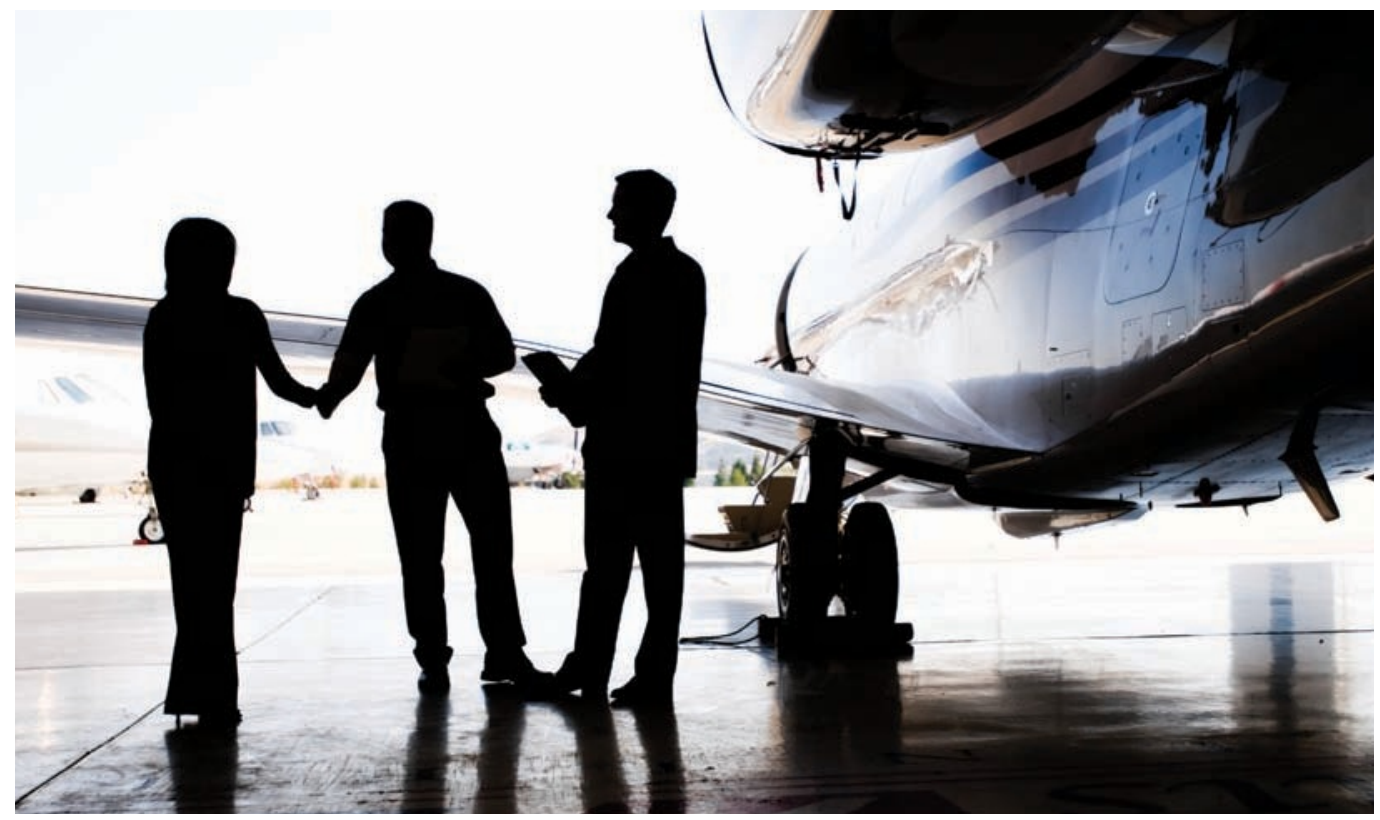

his Twin Beech to air shows up and down the West Coast.

"I got to be his grease monkey while he did air-show routines each summer," says Borgsmiller. "On overnight trips I'd get my own hotel room, which I thought was really cool. I'm lucky my dad allowed it; my mom thought I was way too young." Throughout those years, he also worked in Rust's shop and even managed a fixed base operator (FBO) at Red Bluff Municipal Airport.

Accustomed to filling every minute, during his time at Embry-Riddle, Borgsmiller overhauled aircraft engines part time at Arizona Air-Craftsman in Prescott and spent many weekends as a Coast Guard Reserveyet still managed to graduate and earn Certified Flight Instructor and Certified Flight Instructor Instrument, Multi-Engine Instructor, and Single Engine Sea ratings in 28 months.

"He wanted to learn everything and refused to waste time," recalls Jesse Hustad ('98,

PC), a captain for SkyWest who has known

Borgsmiller since childhood. "It would be impossible to find anyone with a stronger work ethic."

Says Borgsmiller: "All of the flying and airport experience before Embry-Riddle was a great seat-of-thepants education, so I was a really street-smart pilot, but not book-smart. I took some higher-level computer classes at Embry-Riddle's King Technology Center that really helped later on with my business, and courses like meteorology and accident investigation gave me more of a theoretical knowledge base."

\section{A Successful Launch}

After graduating, he flew for Sierra Pacific Industries, served as a regional representative for Texaco Aviation and even did some bartending. In the middle of it all, he got Aviation Consultants Inc. (ACl) off the ground-at the age of 21. By the time he was 24, he had attracted enough business flying charters in a Piper
Seneca out of San Luis Obispo, Calif.-where he's lived ever since-to leave the Texaco job. ing on a sofa bed in my office at the airport," he recalls. "You weren't allowed to live at the airport, but I sort of got around that rule because I was an oncall pilot and mechanic. It was efficient, and in fact, I still do it sometimes, even though I'm married with two kids now." Says Bob Picard ('98, PC), an EmbryRiddle roommate who's now a commercial pilot for JetBlue: "He's always had big goals and ate lots of ramen noodles to get there, so I'm not at all surprised by his success."

$\mathrm{ACl}$ has blossomed into a company that flies 11 jets; manages and maintains corporate fleets; and operates two FBOs (full-service jet centers at the San Luis Obispo and nearby Paso Robles airports). In Borgsmiller's words: "We fly, we fuel and we fix aircraft." About one-third of his 96 employees are pilots and he's hired numerous Embry-Riddle graduates for staff positions and internships.

\section{Flying for Fun}

Borgsmiller's life may sound like all work and no play, but that's only because those lines are so blurred. He earned a rotorcraft license so that one day he could fly to work in a chopper; a seaplane license to land in lakes and "go for a swim right out the door of the floatplane"; and a skydiving license for the "sense of freedom." He's made 650 jumps and admits to being "a bit of an adrenaline junkie."

That was evident when he and some friends at Embry-Riddle resurrected the skydiving club after it had been dormant for a while, found the old club's obsolete gear and hit the road. Not the skies-the road. "I broke my leg parasailing behind a pickup truck," he says, laughing now at the memory. "But that stunt was caught on video and aired on the old show Real $T V$, so it paid for my $\$ 800$ deductible to put the leg back together. I've definitely matured since then, but I'm still willing to try new things."
"I kept the budget in check the first year by sleep-
Bill Borgsmiller ('97, PC) was named one of Airport Business magazine's 2013 Top 40 Under 40 . He advises industry newcomers to accent quality over profits to achieve success.
"He

[Borgsmiller] wanted

to learn

everything and refused

to waste time.

It would be impossible to find anyone with a stronger work ethic." —JESSE HUSTAD ('98, PC), CAPTAIN FOR SKYWEST 
$\cdots \cdots$

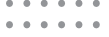

$\cdots .$.

$\because: \cdots$

: :

:

$\because \cdots$

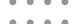

$\therefore .$.

…

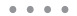

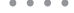

(1)

$\because \cdots$

$\because \cdots$

$\therefore$

$\because: ?$

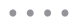

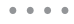

$\because \cdots:$

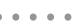

$\therefore$.

$\because \cdots: \cdots$

: :

$\ldots .$.

F

NDI

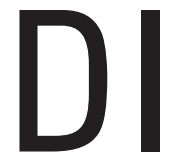

$N$

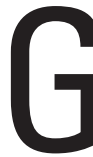

政
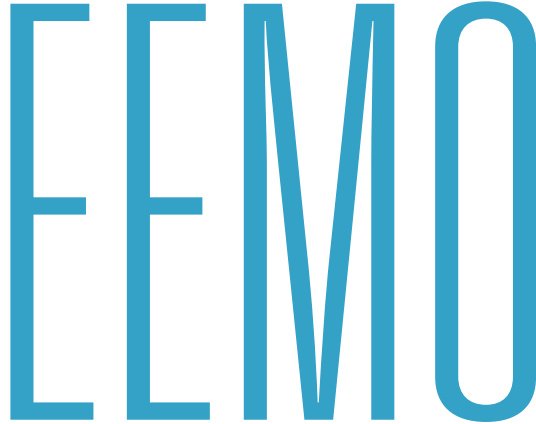

Embry-Riddle teams up with NASA to conduct

\section{research at world's only undersea laboratory}

BY SARA WITHROW

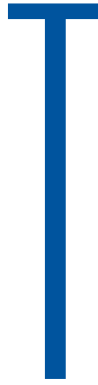

he ocean floor and deep space may be two entirely different environments, but according to astronaut and Embry-Riddle Board member Nicole Stott ('87, DB), there are lots of similarities. In fact, a key component of NASA's astronaut training program is Aquarius, the world's only active undersea research laboratory. "Aquarius is like our underwater space station," Stott says.

"NASA is there because it is the perfect analog to space flight."

Submerged at a depth of roughly 62 feet in the Florida Keys National Marine Sanctuary off the coast of Key Largo, the Aquarius habitat is operated by
Assistant Professor Jason Kring, left, front, adjunct instructor Claudia Ehringer Lucas, right, front, and Teledyne Oil \& Gas engineer Seth Grablow, second from right, pose with CORAL and the NEEMO 19 aquanauts Jeremy Hansen, Randy Bresnik, Herve Stevenin and Andy Mogensen. Also pictured are Embry-Riddle students Austin Leach, Weylin MacCalla and Tyler Rice.

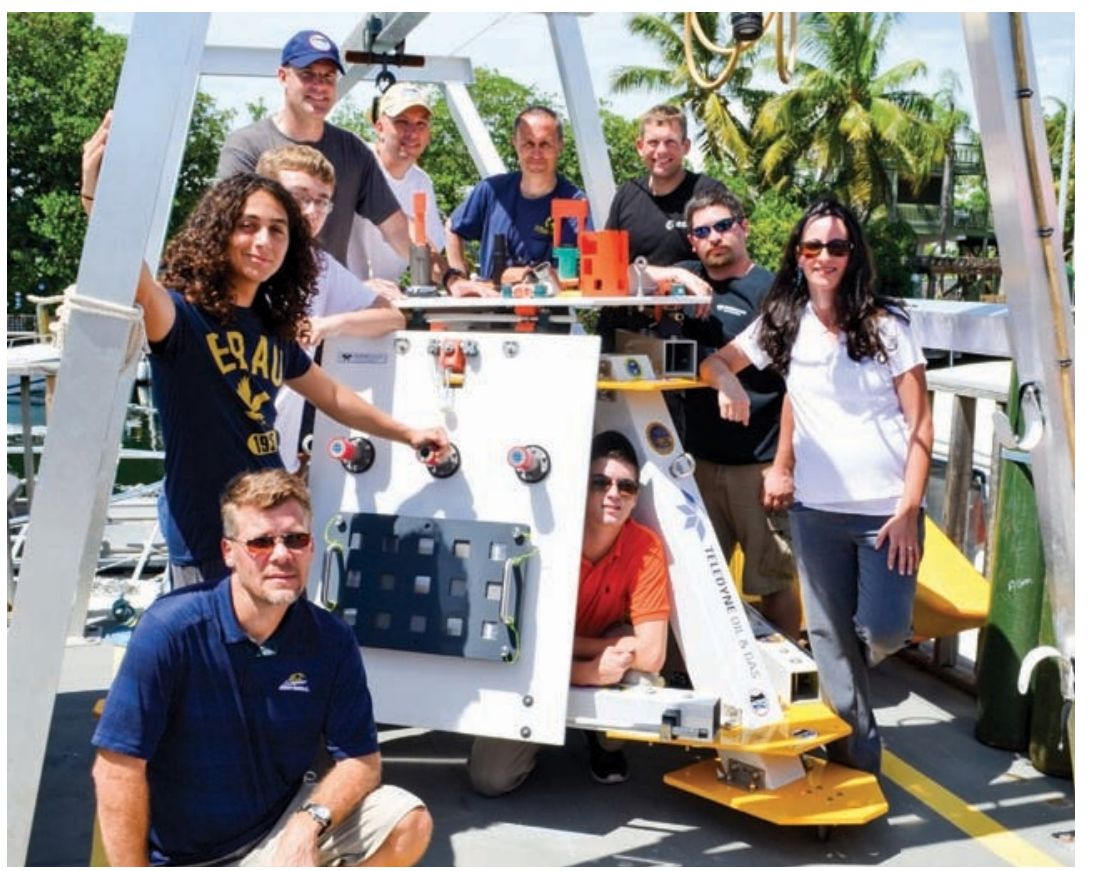

Navy divers secure the Collaborative Oceanic Reliability Analysis Lab (CORAL) to the ocean floor. Built by Embry-Riddle students, in partnership with Teledyne Oil \& Gas, CORAL will be used by astronauts training at the Aquarius underwater habitat. It also represents the first controlled test of Teledyne Oil \& Gas materials in an ocean environment.

Florida International University as a research test bed. Embry-Riddle students and faculty, in partnership with Teledyne Oil \& Gas, a global business with offices in Daytona Beach, Fla., participated in NASA's 19th Extreme Environment Mission Operations (NEEMO) event at Aquarius for 10 days in September.

"It was the most amazing experience I've had at Embry-Riddle, so far," says Carolyn Newton, who completed a Bachelor of Science in Human Factors at the Daytona Beach Campus in December. She and three other human factors students took turns observing operations at the Aquarius Mission Control Center in nearby Islamorada, as representatives from NASA and the European and Canadian space agencies coordinated the activities of four aquanauts, most of whom were training at the underwater facility for future space missions. "We don't always know how we can apply what we learn in the classroom to the real world," Newton says.

"Going to NEEMO opened our eyes to how we can use our degrees."

Newton was impressed by the mission operations team, those working in what will "hopefully become her dream job," but NASA was equally enthused by Newton and her peers. "What we saw from EmbryRiddle was a group of students who were knowledgeable and technically proficient, and who were willing to literally 'roll' with the changing, fast-paced mission environment," says Bill Todd, NEEMO project manager for NASA's Johnson Space Center in Houston. "Their work will help inform NASA in planning future sea and space exploration missions."

The partnership benefited all involved, but mostly the students, says Jason Kring, assistant professor of human factors and primary investigator for Embry-Riddle's NEEMO 19 project. "Students in aerospace engineering, mathematics, human factors and commercial space operations programs got to see how a true NASA training mission is run," he says. "Plus, many of them interacted directly with the astronauts on the crew. This was not a class exercise; this was real."

\section{NASA Connection}

That's exactly the applied learning experience Stott, who trained at Aquarius in 2006 for her first mission to the International Space Station, envisioned when she first suggested Embry-Riddle team up with NASA at Aquarius. Leveraging her NASA connections and working with fellow Embry-Riddle Board member David Robertson and several professors, together they developed projects to integrate with NEEMO 


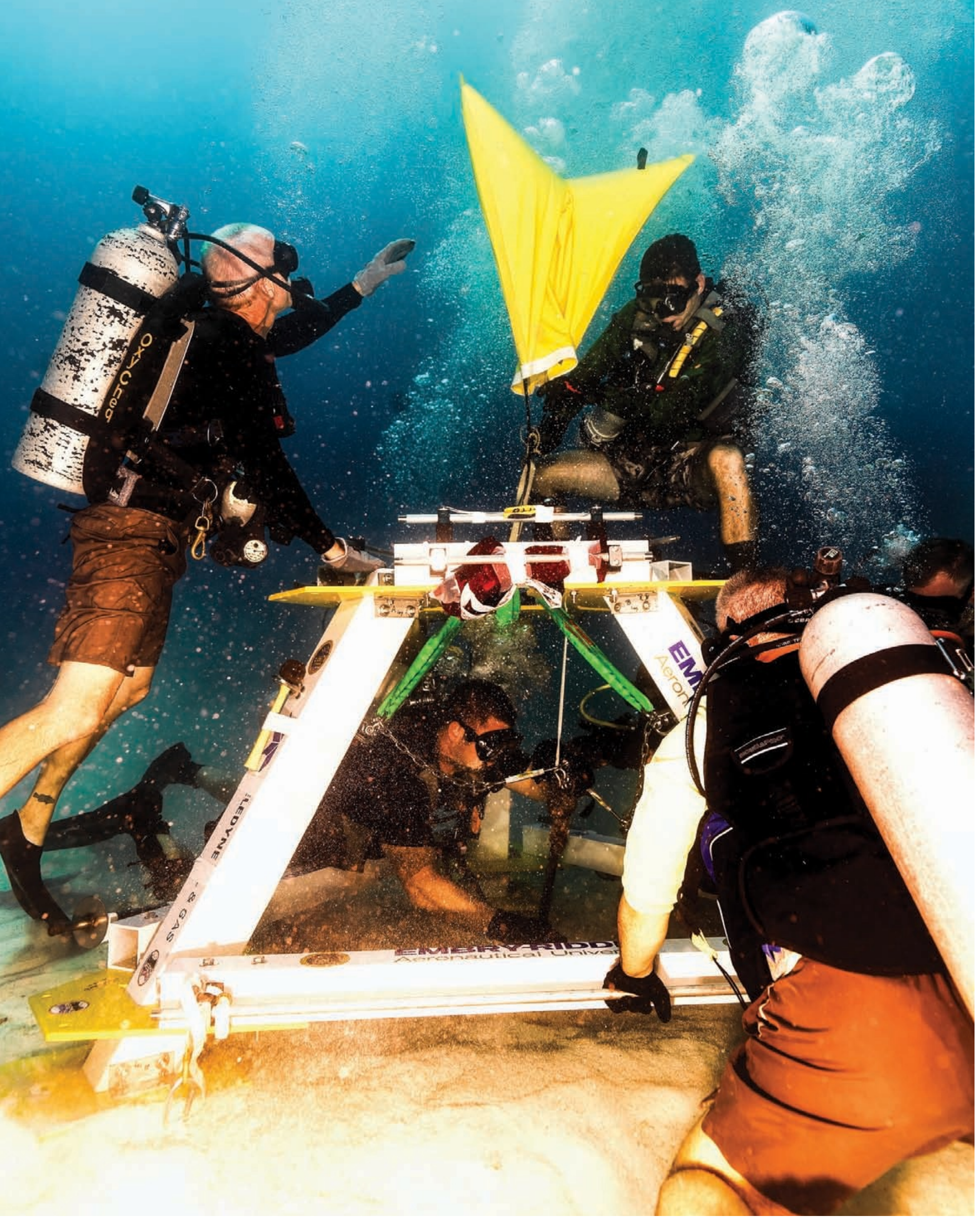


"It took a couple of years, but we finally discovered that the way to get us into Aquarius was to figure out how to self-fund it, pull together some cool ideas for initial research activities and just really and truly get our foot in the door; and I think that's what we did with NEEMO 19," Stott says.

Robertson says hands-on experiences like NEEMO are impactful for students, and that's why he supports them. "It's the difference between our students and those from somewhere else. And, it's a huge difference. They come out of here useful on day one, because of projects like these."

\section{Subsea Partner}

Partnering with Teledyne Oil \& Gas (TOG), a company that produces sophisticated subsea extension cords and connectors for the oil and gas industry, made NEEMO 19 possible, says Glenn Greiner, associate professor and undergraduate program coor-

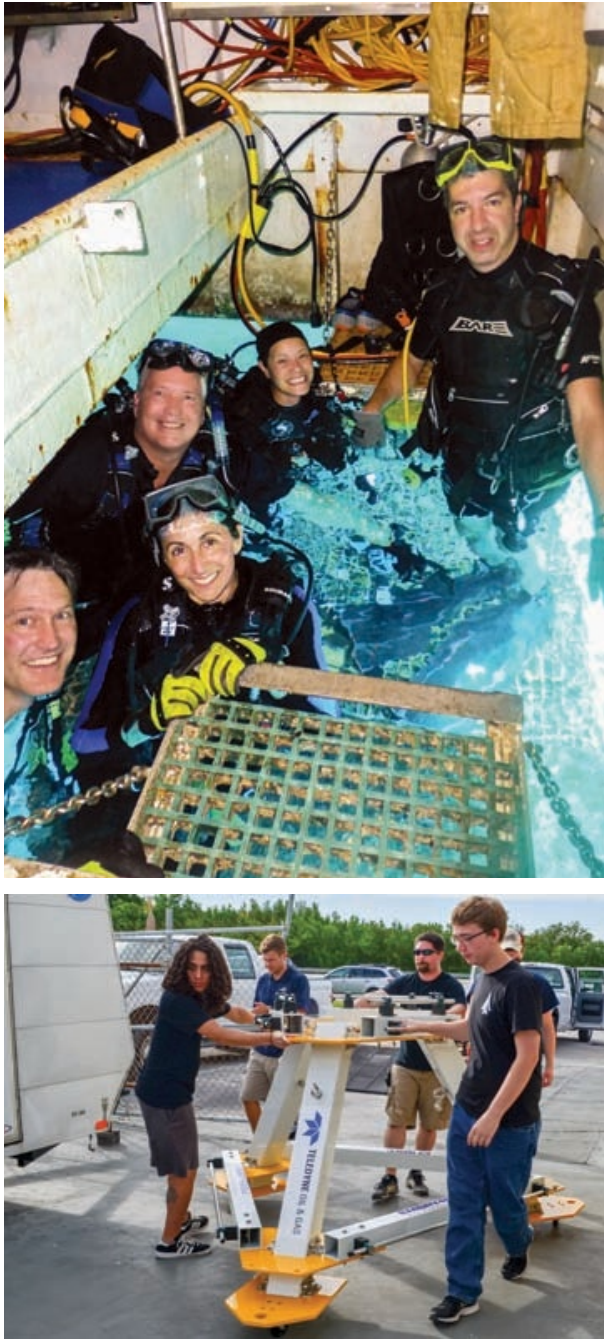
dinator for Embry-Riddle's

Aerospace Engineering program at the Daytona Beach Campus. Greiner made the initial inquiry to TOG. "They were extremely interested in it," he says. "They contributed 50 percent of the cost."

Individual contributions from Stott, Robertson, Greiner and Embry-Riddle's Ignite program for undergraduate research paid the balance.

\section{CORAL}

Not only did TOG contribute to the cost of participating in NEEMO, it also designed, equipped and facilitated the construction of an undersea research platform. Built over the summer by students in Claudia Ehringer Lucas' Engineering Fundamentals 101 class, the Collaborative Oceanic Reliability Analysis Lab (CORAL) includes samples of materials commonly used in TOG's subsea electrical connectors.

"It really reinforced that I wanted to be here at Embry-Riddle," says Weylin MacCalla, a freshman who helped build CORAL. "I don't think at another university it would have happened."

During NEEMO 19, Navy divers guided CORAL to the bottom of the ocean floor and the aquanauts manipulated its removable panels and connectors. CORAL will remain in its subsea location for one year, at which time the materials data, including corrosion,

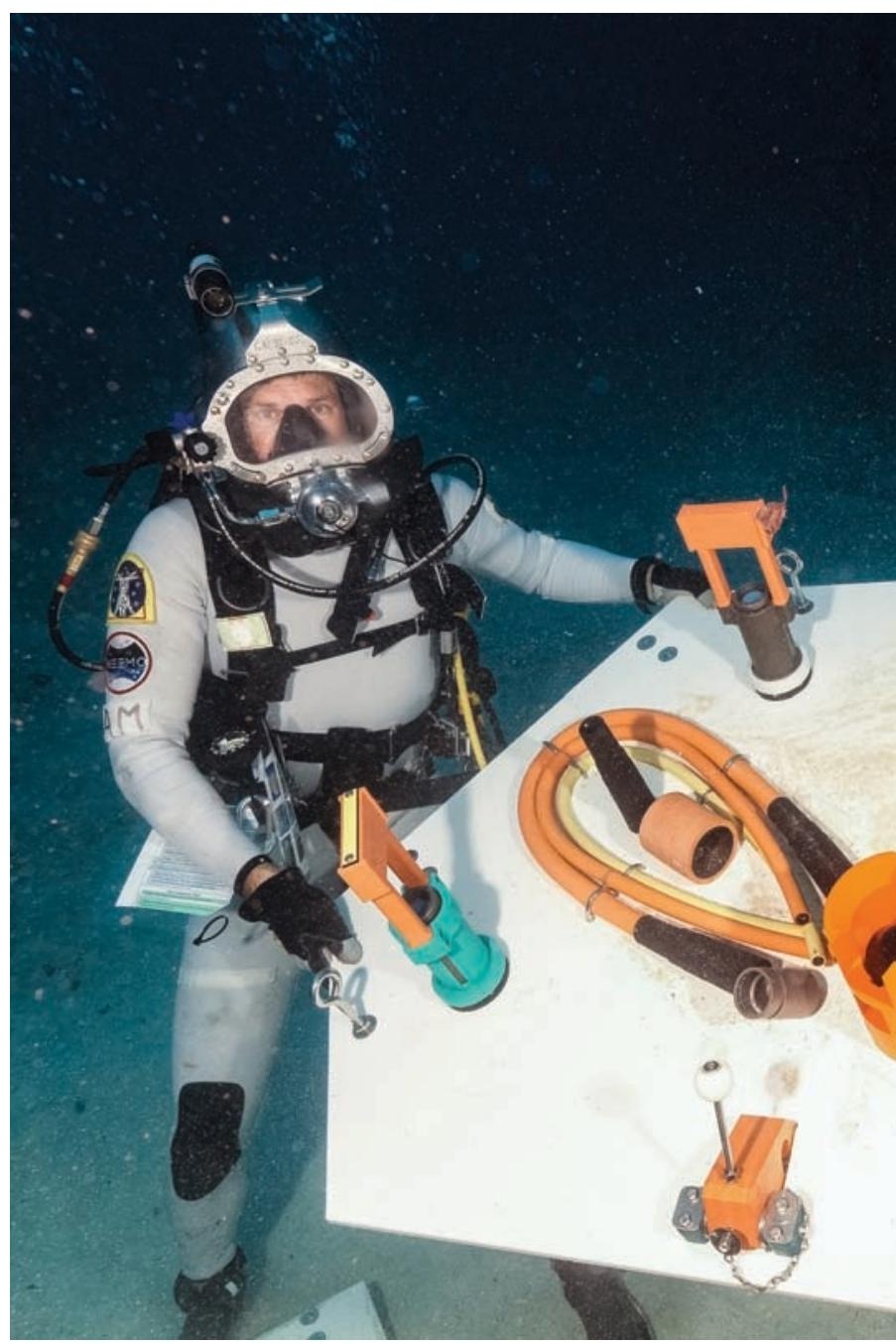

ultraviolet degradation and encrustation results, will be collected and analyzed.

NASA views CORAL as a long-term tool to ben-
Clockwise from top: Embry-Riddle Board members astronaut second from left, and David Robertson, third from left, on the wet porch of the Aquarius habitat, were hands-on participants in NEEMO 19; aquanauts manipulate the connectors on one of CORAL's panels; EmbryRiddle students Weylin

MacCalla, front, right, and Austin Leach, left, front, guide CORAL to the dock in Islamorada, Fla.

\section{RESEARCH INVESTMENT}

To get involved or contribute to Embry-Riddle's NEEMO 20 research projects, contact Chris Lambert at christopher. lambert@erau.edu or 386-323-8827. Nicole Stott ('87, DB), efit its astronaut training exercises. "Future missions might include continued inspection, monitoring of material performance, removal or replacement of modular panels or installation of additional scientific sensing equipment, as a part of the aquanauts' extra-vehicular activities," Todd says.

\section{Smart Business}

TOG scientists Chet Piechowiak and J. Bradley Hunter, who first conceived CORAL, see the project as a success on multiple levels. While TOG's laboratory simulates a variety of deep-sea stressors, this is the first controlled test of materials in an actual ocean environment, Piechowiak says. But partnering with Embry-Riddle is not only smart business; it's about developing the next generation of scientists and engineers, he adds.

"I think back on everything that I've built throughout my career, and it's now retired and has been replaced by new products," Hunter explains. "But Chet [Piechowiak] and I were talking the other day and we said, 'This might be the most important thing we do-build the next group of doers for the world.'" 


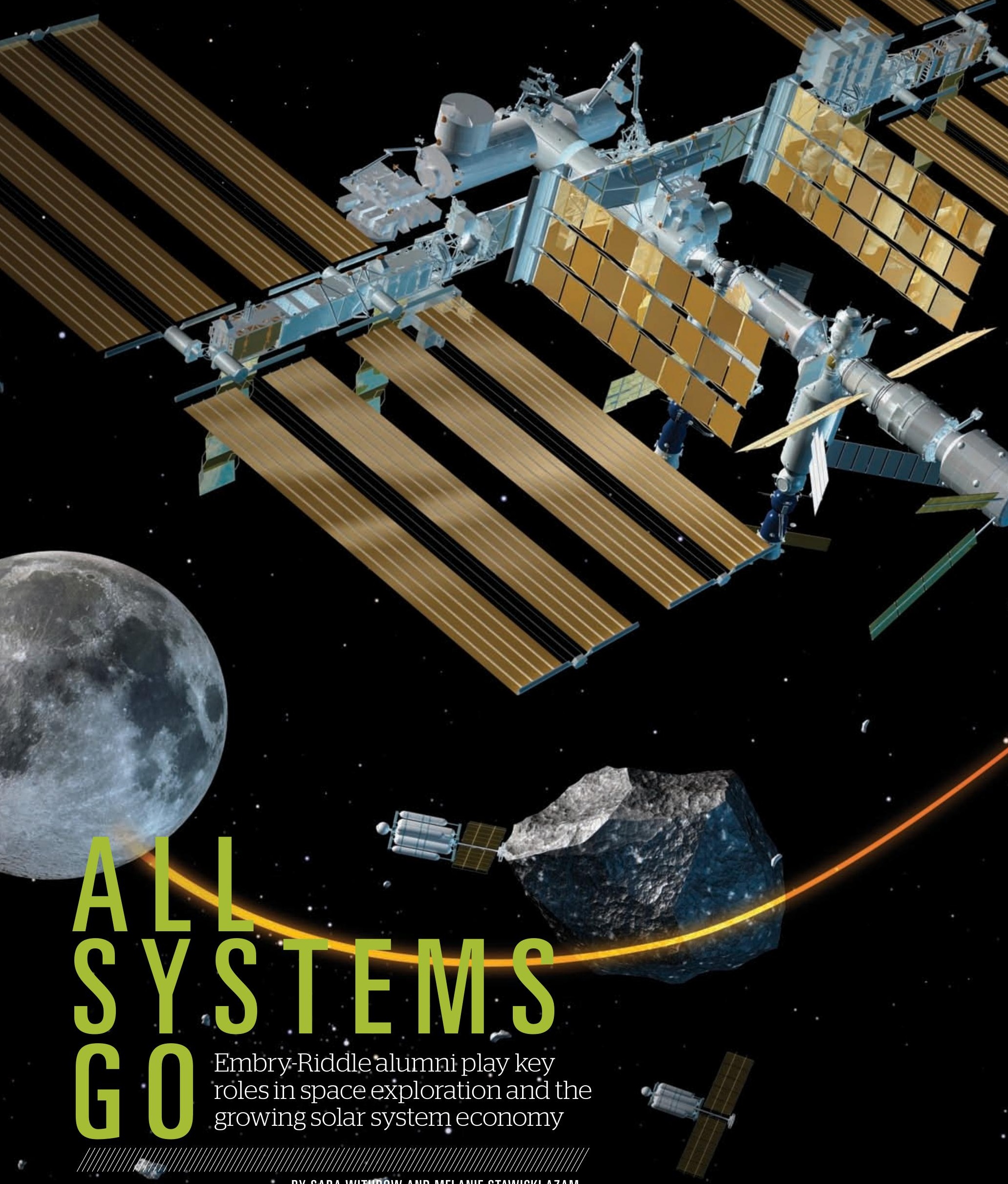




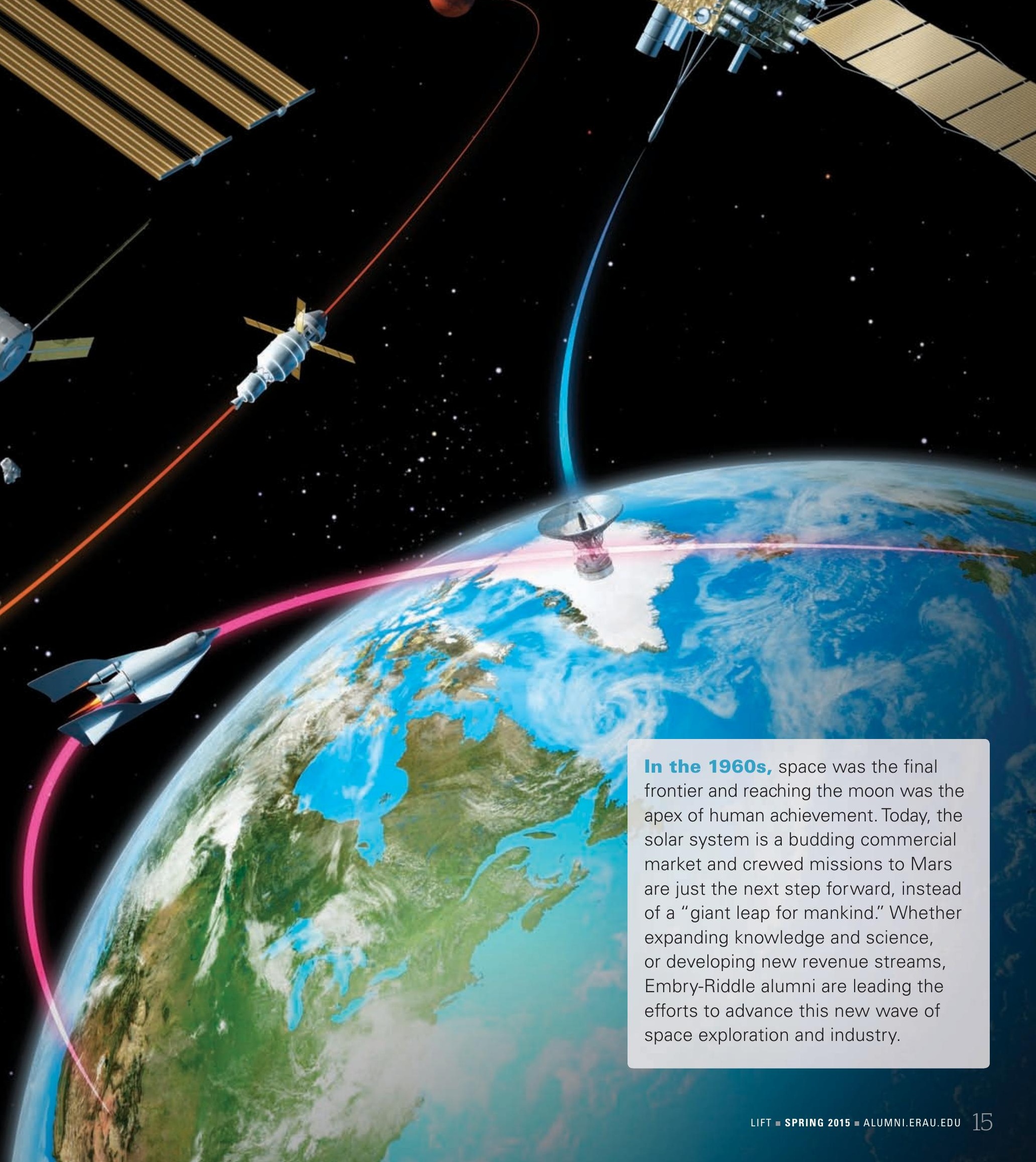




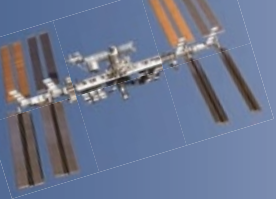

MAKING OUR

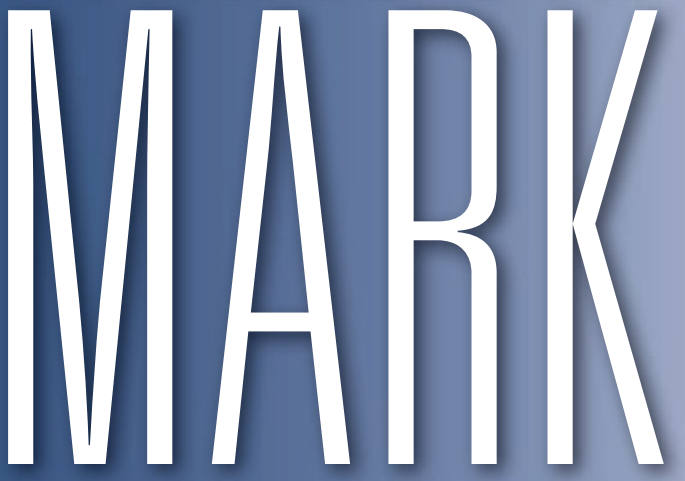

In space and on Earth, Eagles lead and support International Space Station research

BY MELANIE STAWICKI AZAM

Embry-Riddle alumni are making

their mark in the science and operation of the International

Space Station (ISS), as well as in future space exploration. Whether it's researching, spacewalking, "spacetalking" or engineering the latest hardware for the ISS, Embry-

Riddle alumni are hard at work ensuring the success of current and future missions - and paving the way for a new era in deep-space exploration.

\section{Living and Conducting Research in Space}

U.S. Air Force Col. Terry Virts (' 97, WW) is in space now, conducting research at the ISS for Expedition 42/43. He will return to Earth in May. One of six alumni who are NASA astronauts, Virts is slated to conduct spacewalks to prepare the ISS to receive crewed capsules in development. He will also work on some of the 240 experiments onboard the ISS, largely centered on answering key questions that will allow humans to travel to deep space and ultimately to Mars.

This is not the first time Virts, who is commanding Expedition 43, has visited the space station. In 2010, he participated in Space Shuttle Mission STS-130, during which he helped install and retrofit two final permanent modules for the build-out of the station.

"It's like riding a bike," he says, of adjusting to space life, shortly after arriving in the ISS on a Russian Soyuz spacecraft.

Virts is not the only Embry-Riddle alumnus to have had a hand in assembling the orbiting research laboratory. Astronauts
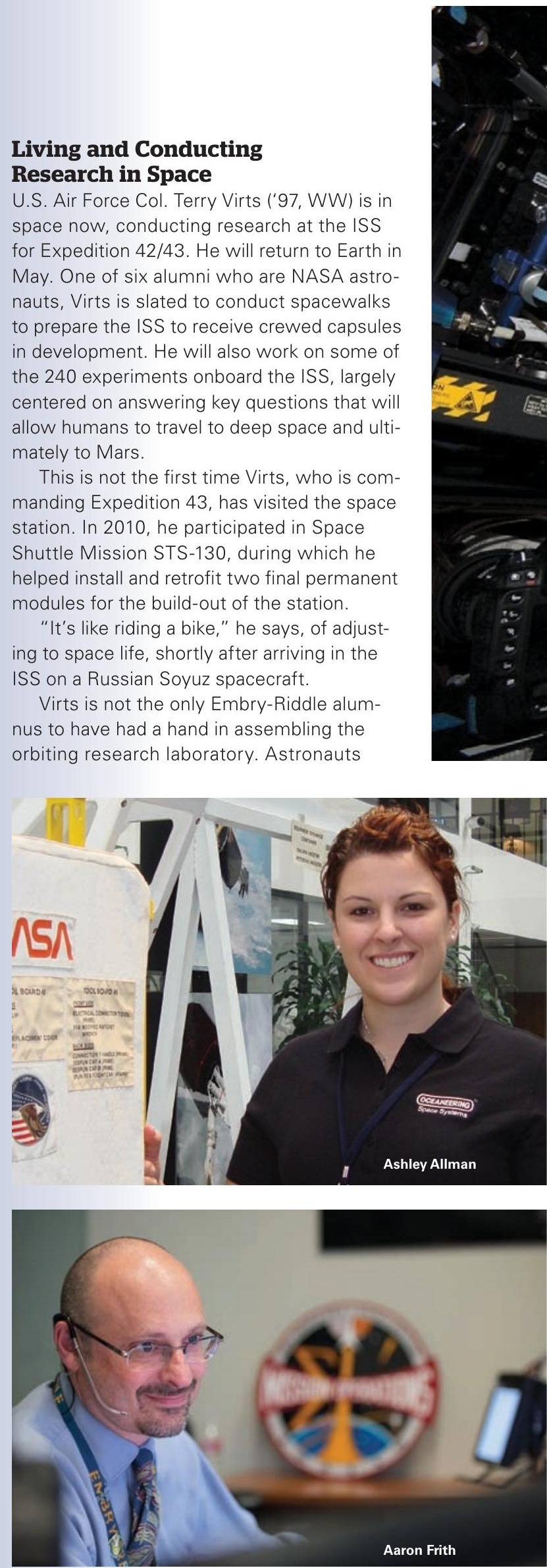


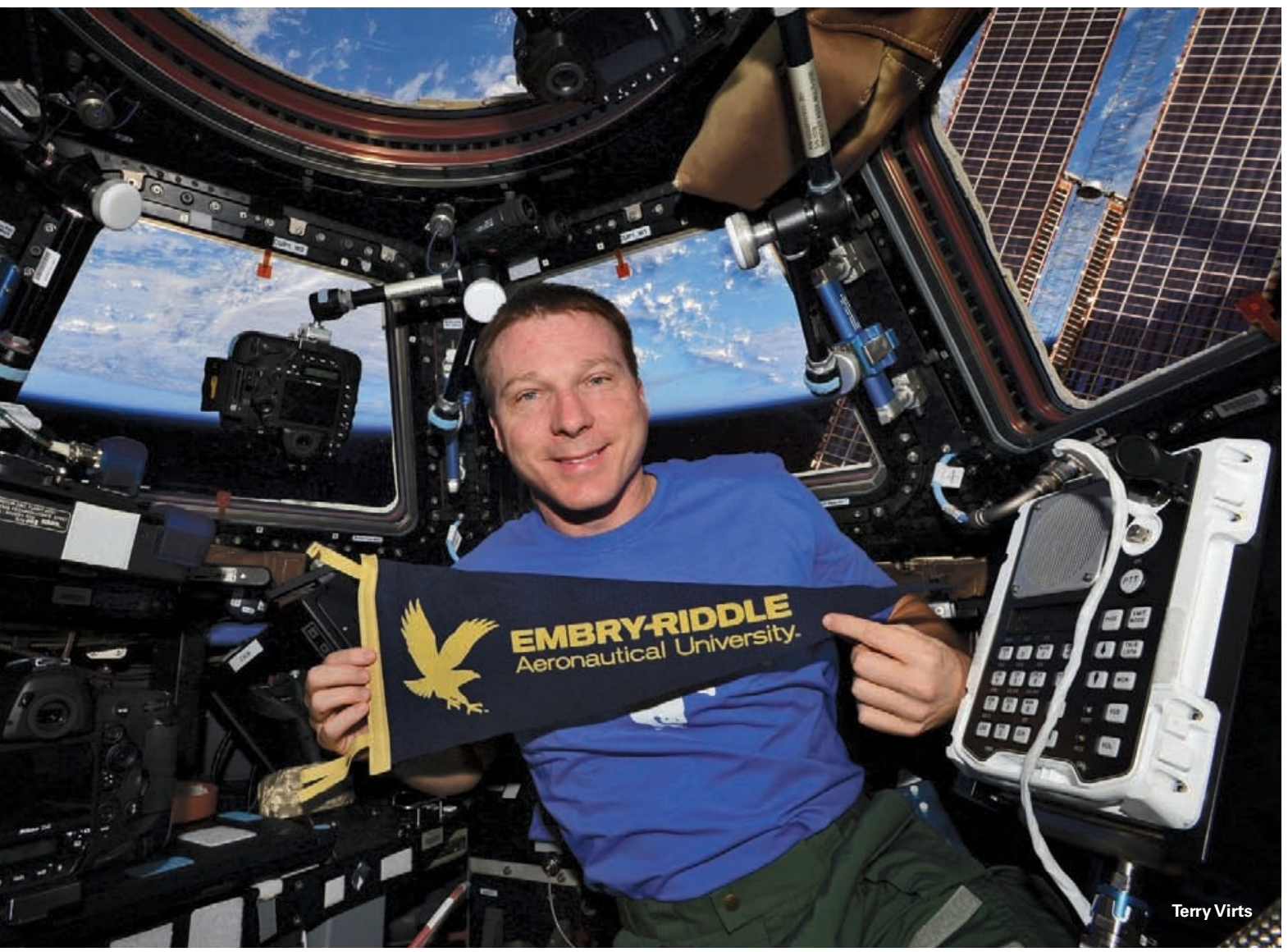

Nicole Stott ('87, DB), who is also an Embry-Riddle Board member, Col. Alvin Drew ('95, WW), Capt. Dan Burbank ('91, WW) and Col. Ronald Garan ('95, WW) also delivered and constructed portions of the station during previous space shuttle missions; and Norman Knight ('90, PC), former space shuttle flight director, now chief of the Flight Director Office at Johnson Space Center, oversaw many of these missions.

\section{Keeping Communication Open}

While Virts is "walking the walk," living and working in space, it's Aaron Frith's ('95, PC) job to ensure that ground control and the astronauts continue "talking the talk." As a ground controller at Johnson Space Center for the past 10 years, Frith works to ensure smooth, unbroken communications between the ISS and NASA Mission Control. Employed by Lockheed Martin, a NASA contractor, Frith oversees all data and voice lines entering and leaving the mission control center to and from the ISS, and the scheduling of satellites to relay these signals.

"The first time I drove through the gate at Johnson Space Center-what an incredible feeling," Frith says of his job at NASA.

Although he loves his work, it can also be stressful. He recalls the time a crew member exited the ISS to do a spacewalk and there was a call that the satellite had just timed out, meaning communications would be lost for 40 minutes. "That was the most stressful 38 minutes of my life," he says.

Frith, who earned a B.S. in Aeronautical Science at the Prescott Campus, is also the overall ground lead for the Orion project, NASA's newest spacecraft designed to carry astronauts into deep space. Orion's first test flight was successfully conducted on Dec. 5, 2014. "It was very emotional for me," Frith says. "We dedicated the last three years preparing for this mission and it was nearly flawless.

"This Orion spacecraft is the ladder to allow us to go to the moon and Mars."

\section{Engineering for Space}

Ashley Allman ('13, PC) will never forget the spectacle of watching the final shuttle launch from Cape Canaveral. "We were 10 miles away and the power of the engines almost made my heart stop-it was incredibly inspiring," she recalls.

Like many Embry-Riddle alumni, Allman's love of flight includes a passion for space. After four internships with NASA and NASA contractors, the Seattle native landed her dream job engineering hardware for the ISS. "I love it," says Allman, a One EVA engineer at Oceaneering Space Systems in Houston. "I've utilized the engineering skills that I learned at Embry-Riddle in every phase of the design process. That knowledge has been invaluable."

Allman sees a lot of growth ahead, especially in the commercial space sector, and eventually hopes to make it to space herself someday. "I would absolutely take advantage of that. But if that never happens for me, I'll be happy working in the background to make it possible."

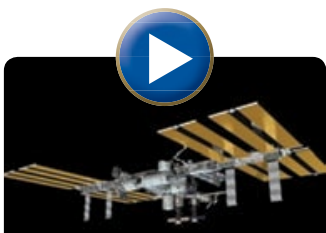

WATCH

Col. Terry Virts arrives at the International Space Station; and his impressions on the launch and life in space.

http://bit.ly/1GXpimV http://bit.ly/1vbHvES 


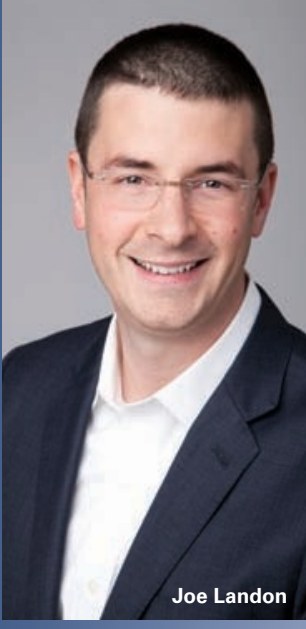

SPACE RUSH Joe Landon $\left({ }^{\prime} 01, \mathrm{DB}\right)$ is leading a new industry set on mining asteroids

\author{
BY SARA \\ WITHROW
}

\section{EDUCATING}

FUTURE SPACE ENTREPRENEURS

Embry-Riddle launched the nation's first Commercial Space Operations degree in January 2014. The program focuses on policy, operations, human factors and planning elements of commercial and private space operations.

http://daytona beach.erau.edu/ degrees/bachelor/ commercial-spaceoperations
Like the gold prospectors of the American West, Joe Landon ('01, DB) and the company he works for, Planetary Resources, have identified precious metals and elements on unclaimed lands. "Hydrocarbons, organic compounds like water, iron, platinum and other metals; anything that you need, it's there," he says.

The only problem: These valuable resources are up to 92 million miles from the Earth-on asteroids. But that doesn't deter Landon, who is vice president and chief financial officer for Planetary Resources. He envisions a commercial space industry where resources are mined and processed robotically and then transported by spacecraft to any number of customers, also in orbit. "Now that we have advanced technologies, we can go out and expand the economic sphere of the Earth to include these resources," he says.

Planetary Resources has identified a top 10 list of near-Earth asteroids for initial exploration and expects its first exploratory mission to launch in the next few years. But that's just the start. There are tens of thousands of near-Earth asteroids, and more being discovered each day, which are located within an accessible one Earth-sun distance from the planet's surface.

While a lot of exploratory work needs to be done before mining can begin, water, in the form of ice, will likely be the focus of the first mining missions, Landon says. "Water is made of hydrogen and oxygen atoms, which we can split, and then you have liquid hydrogen, or rocket fuel. This could change the economics of the satellite industry by making it possible to refuel your satellite in space."

\section{Engineering Start}

With a B.S. in Engineering Physics from Embry-Riddle and an M.S. in Aerospace Engineering from the University of Southern California, Landon's interests were firmly centered in development and design. But while working for Boeing's Space and Intelligence arm at the epicenter of the emerging commercial space industry, he had an epiphany. "I saw this industry unfolding and I realized that while it would need lots of engineers, what it would really need is leaders and business people to help shape it."

He switched his focus to business, earned a Master in Business Administration from Harvard Business School, and a few years later, joined forces with Eric Anderson, co-founder of Planetary Resources and Planetary Power, a renewable energy business. In 2012, Landon added CEO for Planetary Power to his nameplate, as well. While he's dedicated to both enterprises, the prospecting and eventual mining of asteroids represent the toughest challenges as well as the biggest opportunities.

"What fascinates me is the opportunity to do something that will have a lasting impact on our civilization," he says.

He forecasts a thriving industry, to include active asteroid mining, within the next 20 to 30 years. "Imagine taking a 3D printer to an iron asteroid and printing out a space station." It may sound far-fetched, but it's certainly possible, he says. "All the technology to do this is within our reach. We never say it's going to be easy, but it's definitely worth doing."

\section{SUBORBITAL TRANSPORTATION}

Oscar Garcia ('O4, DB), chairman and CEO of InterFlight Global Corp., who also chairs the Standards Working Group as a member of the Federal Aviation Administration's Commercial Space Transportation Advisory Committee, sees high-speed, point-to-point suborbital spacecraft as the next evolution for air transportation. "The air transportation world as we know it revolves at below Mach 1. It takes 36 hours to get 'door to door' from and to the farthest points on the globe," he says. "I want to go from where we are today to point-topoint transportation at around Mach 10 speeds."

A strategic business and space transportation industry consultant, Garcia says the scalability of the jet-rocket-jet business makes it lucrative from an investment standpoint. "When you consider that almost 3 billion passengers flew globally this past year, if only 1 percent were to take advantage of point-to-point suborbital travel, you'd have roughly 30 million customers the first year," he says. "The volumes are there. This is what would open space to the masses in a very meaningful way."

Garcia is working with technologists, operators and investors to develop a proof of concept commercial space vehicle within the next 10 years. The fatal crash of Virgin Galactic's SpaceShip Two rocket in October 2014 was a setback, but not a "showstopper," Garcia says. "The bottom line is human space flight is dangerous.... [But]we have to risk to achieve."

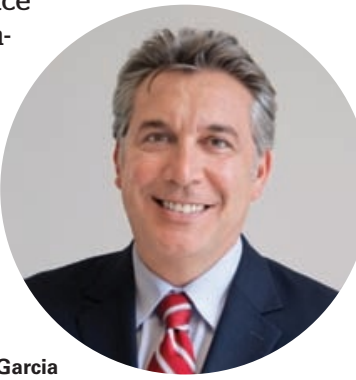




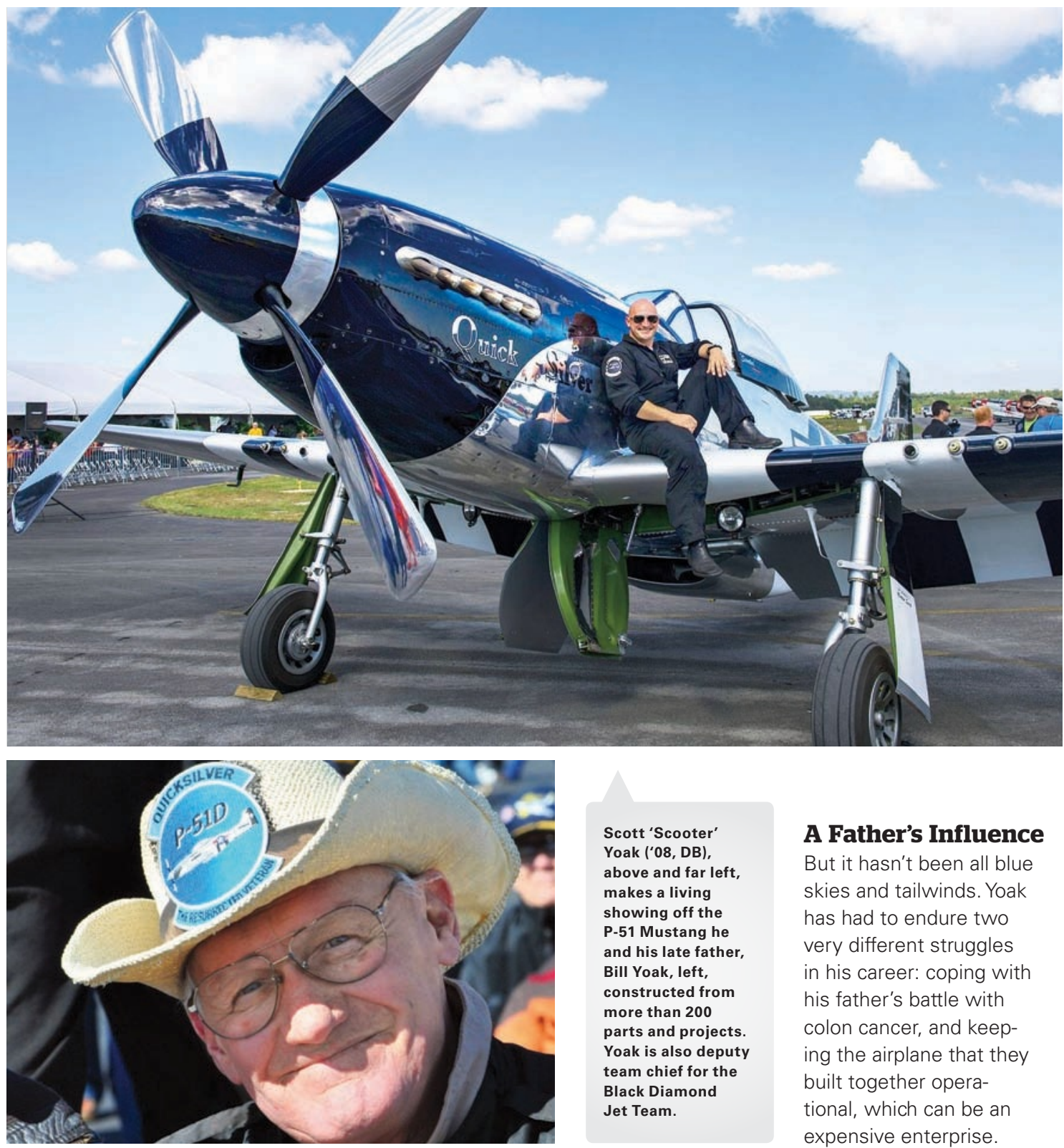

Embry-Riddle, then sought an aerobatic pilot's license. The year he received his license, he was scheduled for 10-plus air shows. In 2014, he performed in 22 different shows, his busiest season yet. In his downtime, he serves as deputy team chief for the Black Diamond Jet Team

"Usually when you first start, you'll get maybe three or four air shows a year. It's not about me, it's about the airplane. People want to see it," says Yoak. "A lot of it is going out there, doing your time, doing smaller shows, and maybe doing things that you don't find exactly fun at the time."

His fellow Phi Delta Theta fraternity brother Joseph Marco ('11, DB) says Yoak was determined to succeed, even as a student at Embry-Riddle. "He's very knowledgeable and passionate about the things that matter to him," Marco says. "He sets a great example for the things that one can achieve with the right mindset and perseverance."

\section{Scott 'Scooter' Yoak ('08, DB), above and far left, makes a living showing off the P-51 Mustang he and his late father, Bill Yoak, left, constructed from more than 200 parts and projects. Yoak is also deputy team chief for the Black Diamond Jet Team.}

\section{A Father's Influence}

But it hasn't been all blue skies and tailwinds. Yoak has had to endure two very different struggles in his career: coping with his father's battle with colon cancer, and keeping the airplane that they built together operational, which can be an expensive enterprise.

"I lost him in March

2013 to colon cancer. He fought it very bravely for five years; unfortunately he lost," says Yoak, who started rebuilding the Mustang with his father at the age of 9. "He's with us; he's with this airplane." The P-51 Mustang, known as "Quick Silver," that they built together from more than 200 Mustang parts and projects was originally constructed in 1945 as a fighter plane for World War II. It is Yoak's (and his father's) mission to honor American veterans through its performances.

Yoak credits his father for his success in aviation. "My dad gave me the opportunity to get where I am today. Anybody can stroke a check and get one of these airplanes, but not everyone can take one of these airplanes and give you the stepping stones to go from flying a Cessna 172 to a P-51. My dad did that, and he did it at a very prescribed, deliberate pace. It was my father; he was the main, driving force that got me to where I am," he says. *

\section{GIVING BACK}

Despite the loss of the man who taught him everything he knows about flying, Scott Yoak's Quick Silver performance team will soon have one less problem to worry about. "I'm working on being fully sponsored. It looks very promising for 2016," he says.

The sponsorship is just one step in the evolution of his business. Yoak also wants to increase his involvement in outreach to younger generations. Flying used to be more about himself and fueling his ego, he says, but now he wants to give back to the aviation industry by inspiring future air show pilots.

"How are we going to inspire them, if we don't show them what it's able to do? It's one thing to see this aircraft in a museum, but you don't get to hear it, or experience the vibrations in the engine noise, the sights, sounds, smells and even taste," Yoak says. "Air shows give you that, and I'm glad to be a part of it." 


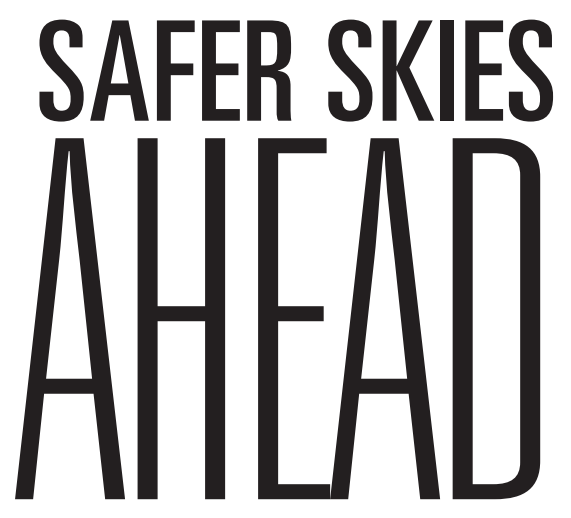

First-ever crashworthiness fellowship awarded to Prescott Campus graduate student

\section{BY MELANIE STAWICKI AZAM}

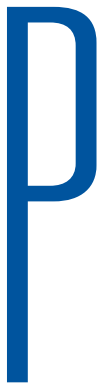

artnering to support research aimed at making the skies safer, the Robertson Family and the International Society of Air Safety Investigators (ISASI) have awarded through the Robertson Safety Institute (RSI) at Embry-Riddle's Prescott Campus their first-ever ISASI-Robertson Fellowship to graduate student Raymond Gallardo.

The fellowship, made possible by initial gifts from the Robertson family, and participation by ISASI, allows graduate students to conduct research on crashworthiness and air accident investigation while working with RSI. In addition to receiving full tuition coverage, fellowship participants have access to research and travel funding for approved projects.

The fellowship was welcome news to Gallardo, who was struggling financially to pursue his master's degree in safety science. "Now that I have the support of the fellowship, I am able to conduct multiple research projects to support my graduate thesis," he says.

The newly formed partnership between the Robertson Family and ISASI, working through RSI, will help Embry-Riddle grow the program, enabling it to fund additional assistantships and fellowships, as well as provide needed research and development dollars to advance aviation safety.

Commenting on the partnership, ISASI President Frank Del Gandio noted, "As the only organization solely dedicated to the interests of the air safety investigative community, ISASI is proud and honored to partner with the Robertson Family in creating opportunities to further the field of crashworthy research and investigative safety development."

Erin Bowen, chair of Embry-Riddle Prescott's
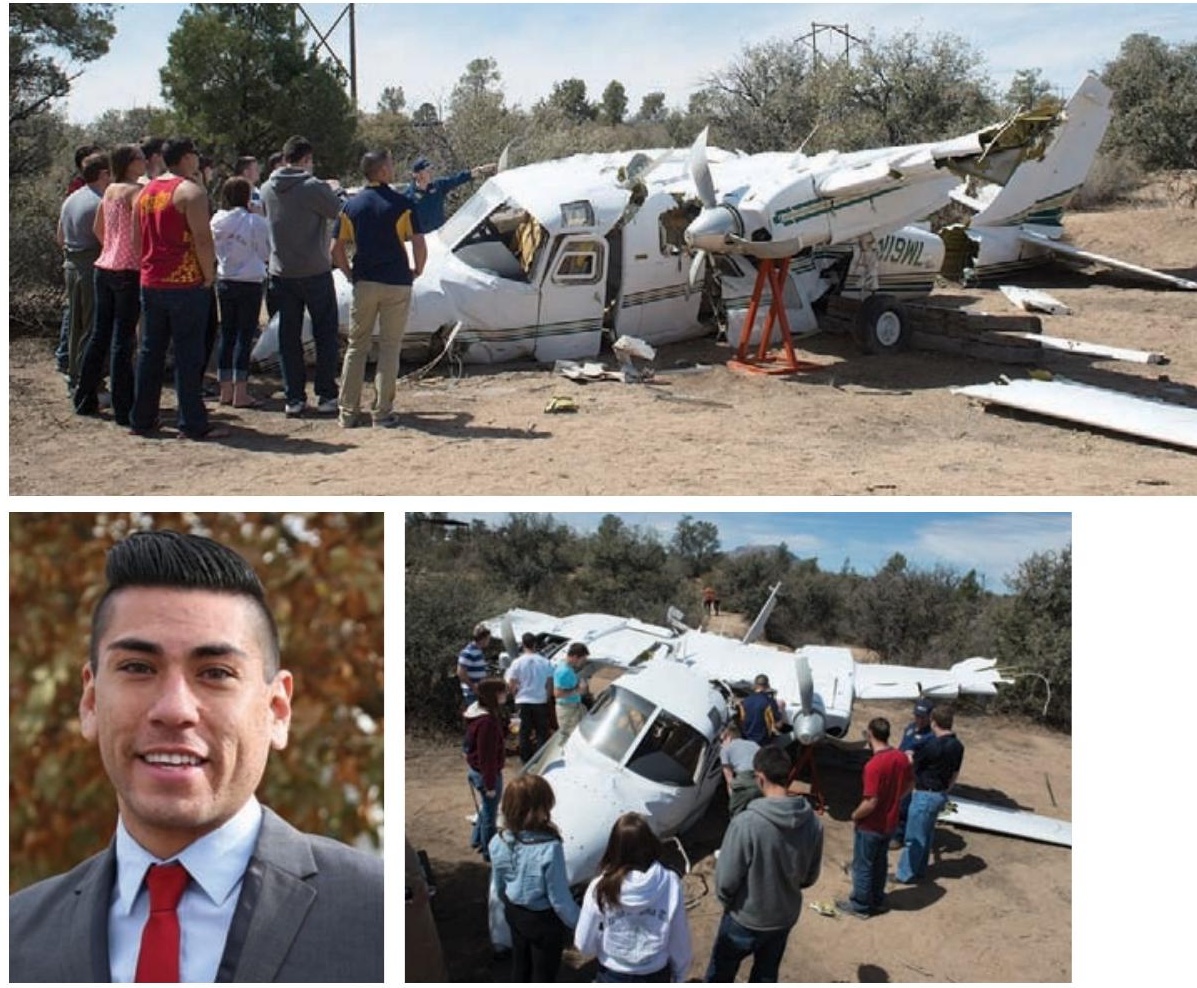

Behavioral and Safety Sciences department, which includes the RSI, sees the partnership as an opportunity for Embry-Riddle to lead in aviation safety research and increase its international recognition.

"It gives us the ability to allow scholars to focus on advancing the science and practice of safety, conducting complex field or laboratory experiments, and becoming the next generation of aviation scientist-practitioners," she says.

Established in 2012, RSI fosters and supports research in crashworthiness, crash survival and other related safety initiatives in a field of study pioneered by S. Harry Robertson. An emeritus trustee of Embry-Riddle, Robertson invented the Robertson Crashworthy Fuel System. His aviation safety research is preserved at the Prescott Campus's Aviation Safety and Security Archives.

"Aircraft accident investigators must collect and store data so researchers and design engineers can access that data in order to address the cause of injuries and fatalities related to design," says Robertson. "[We] hope to promote and provide those capabilities through Embry-Riddle's Robertson Safety Institute and its fellowships."

Richard B. Stone, ISASI executive adviser and past president, says Robertson's deep ties with ISASI made the organization eager to support his efforts. Robertson is a founding member of ISASI and a recipient of its Jerome F. Lederer Award. ISASI represents more than 1,500 professional accident investigators from more than 70 countries and about 145 industry-related corporate members.

"Harry has been such a stalwart in ISASI since the founding of its first chapter that it was clear ISASI should join in this fellowship effort," says Stone.
Graduate student Raymond Gallardo, left, is the inaugural recipient of the ISASIRobertson Fellowship. Top and bottom, students learn the intricacies of accident investigation at the Robertson Aircraft Accident Investigation Lab at the Prescott Campus. f Giving Just Giving to EmbryRiddle is now on Facebook! Just visit www.facebook.com/ GivingToEmbryRiddle. 


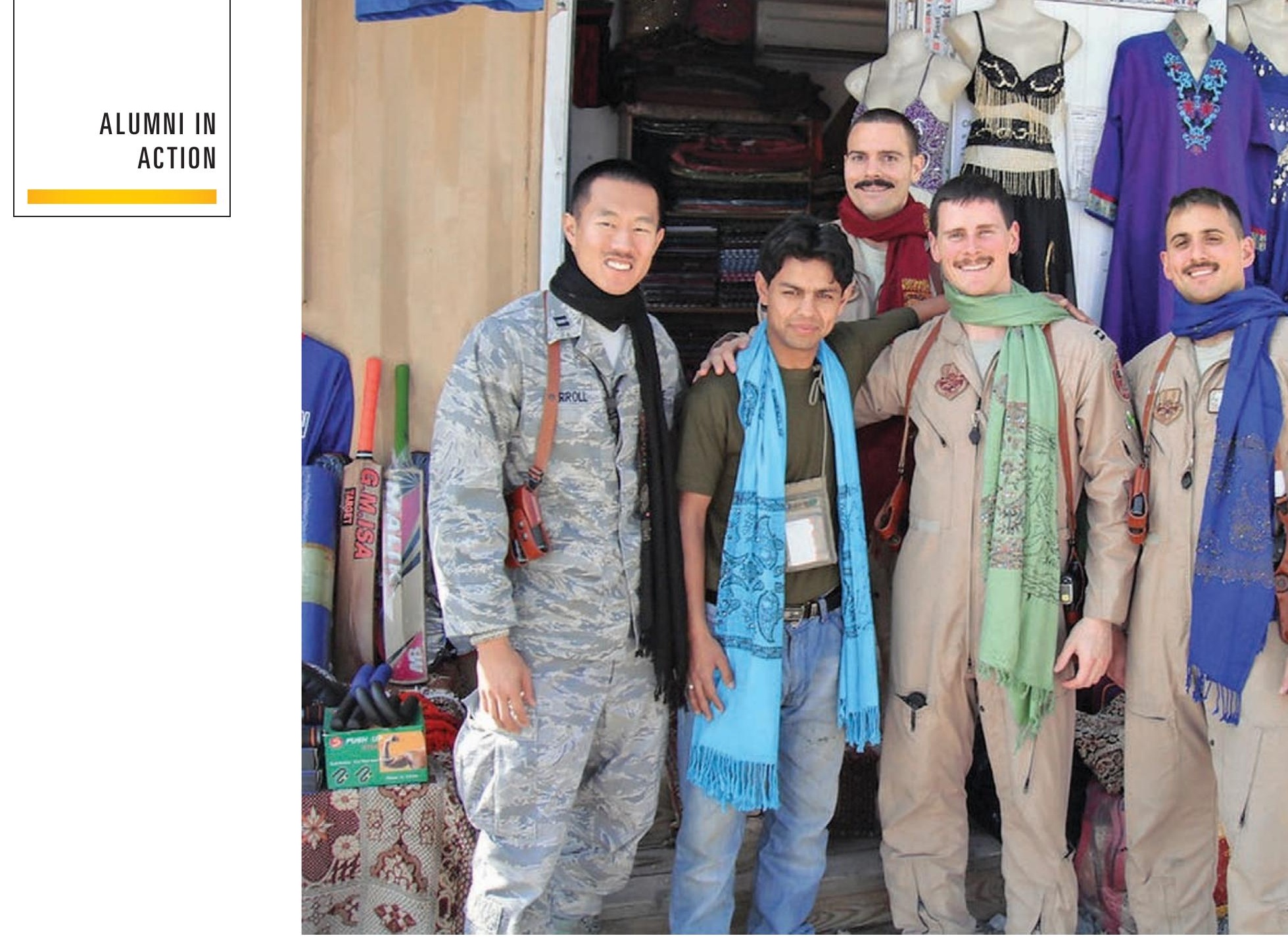

\section{Changing Lives, One Scart at a Time}

\section{Alumnus co-founds} nonprofit to benefit Afghan widows and their families

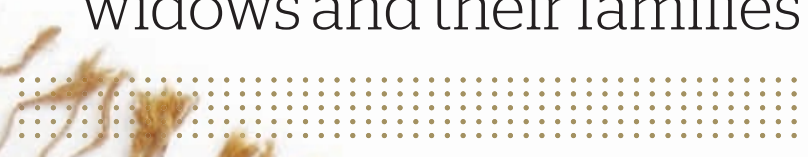

BY SARA WITHROW

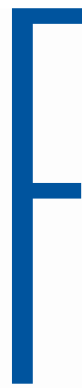

lying combat missions over Afghanistan in 2011, U.S. Air Force Capt. Joseph Stenger ('06, DB) was struck by the futility of the U.S. effort to eradicate the Taliban's entrenched socio-political and military influence. "You fly enough combat missions and you realize that the bombs you're dropping have very limited lasting effects," he says.

Seeking greater understanding of the Afghan people, he and fellow Air Force officers Capt. Joshua Carroll, now a major in the Air Force Reserve, Capt. Jonathan Hudgins and Capt. Ryan Bodenheimer went shopping at the bazaar on base. "We wanted to engage the locals," Stenger says.

Meandering through an assortment of handicrafts sold by residents of the neighboring villages, the foursome encountered a mother and son selling hand-beaded scarves sewn by Afghan widows. "Every widow has extra obstacles in life," Stenger says. "But in Afghanistan it's worse because the culture and Sharia [Islamic] law dictate that women can't, or shouldn't, work. They have no way to make an income. This woman and her son were providing employment for widows." 


\section{ALUMNI NEWS}

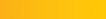

\section{MESSAGE FROM THE ALUMNI ASSOCIAIION}

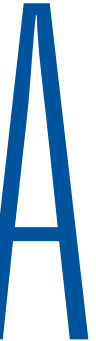

s I write this letter for the spring edition of Lift, my thoughts go back to 50 years ago this April, when Embry-Riddle moved from Miami to its new home in Daytona Beach, Fla.

In the process of transitioning what was then Embry-Riddle Institute into a fully accredited university, newly elected President Jack Hunt spearheaded the move, which would become known as "Operation Bootstrap."

Here we are 50 years later, with close to 120,000 alumni and nearly 32,000 students taking classes in Daytona Beach, Fla., Prescott, Ariz., and at more than 150 Worldwide Campus locations in the United States, Europe, Asia and the Middle East.

Our alumni have paved the road for up-and-coming graduates and the pedigree of our achievements is humbling. Embry-Riddle alumni know that there is no room for error; and because of them missions have been completed, lives have been saved, countries have been defended and our reputation for educating and training the best continues to reach well beyond the dreams of our founders.

The success of our alumni is depicted in national

\section{Please contact me} with your suggestions at william.thompson @erau.edu. rankings and surveys. Statistical data from the most recent Embry-Riddle Alumni Survey show that 96.6 percent of graduates from the Daytona Beach and Prescott campuses obtained employment in their field of study or continued their education, within one year of graduation Embry-Riddle Prescott and Embry-Riddle Daytona Beach rank in the top 65 out of over 1,000 universities for 20-year return on investment; and the vast majority of our alumni state in a recent graduation survey that-YES, they would do it all over again.

A common denominator among Eagle graduates is the passion we share for the aviation/aerospace industry and the respect and gratitude we have for our alma mater A testimony to this fact: More than 700 alumni attended our 2014 homecoming activities, which included the Wings \& Waves and Wings Out West air shows.

Please take time to celebrate your achievements; remember the "E" from ERAU and stay "Engaged" with your alma mater; and let us know about your accomplishments.

\section{Thank you for being Forever an Eagle,}

Bill Thompson ('87, PC)

Executive Director

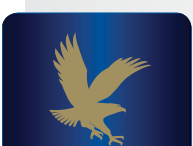

\section{CHECK OUT THE ALUMNI APP}

Looking for an Embry-Riddle Alumni event in your area? We've got an app for that-and so much more, and it's free! Search for "Embry-Riddle

\section{ERAU} select the "Alumni Association" tab after downloading.

www.facebook.com/ERAUAlumni

www.twitter.com/ERAU_Alumni

Search Embry-Riddle Aeronautical

University Official Alumni Group
Join the Eagle Network:

alumni.erau.edu/join

www.flickr.com/photos/eraualumni
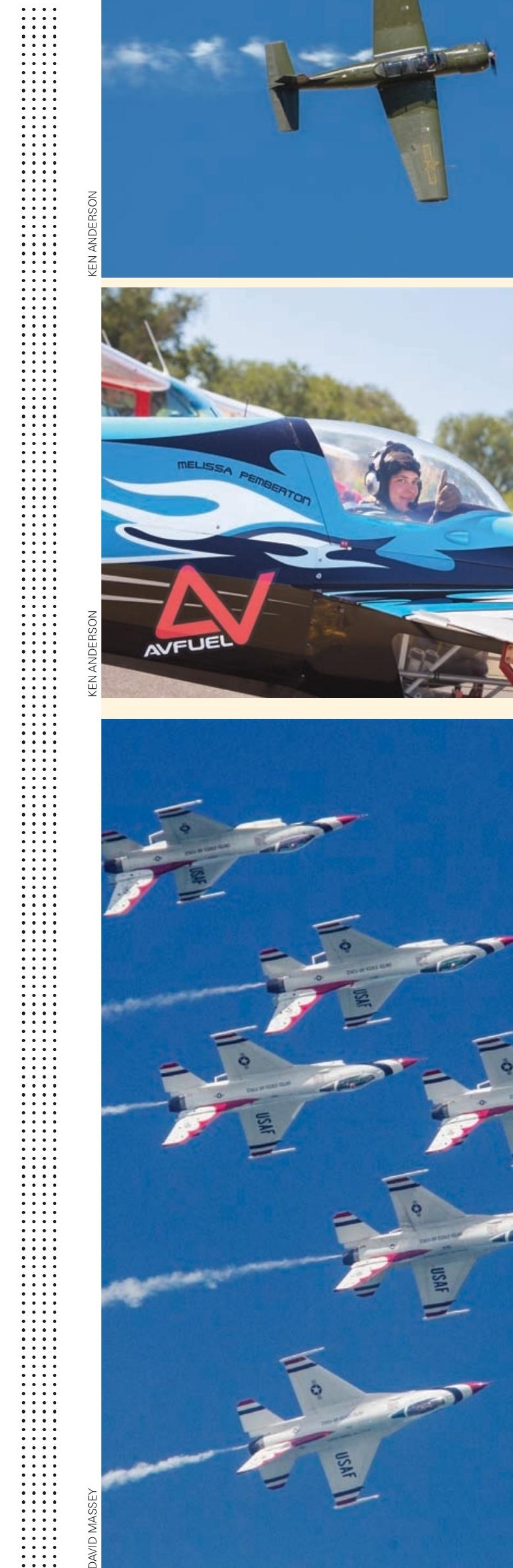
OctoberWest Alumni Homecoming Weekend and Wings Out West Air Show

Prescott, Ariz. $\bullet 2014$

$::::::::::$
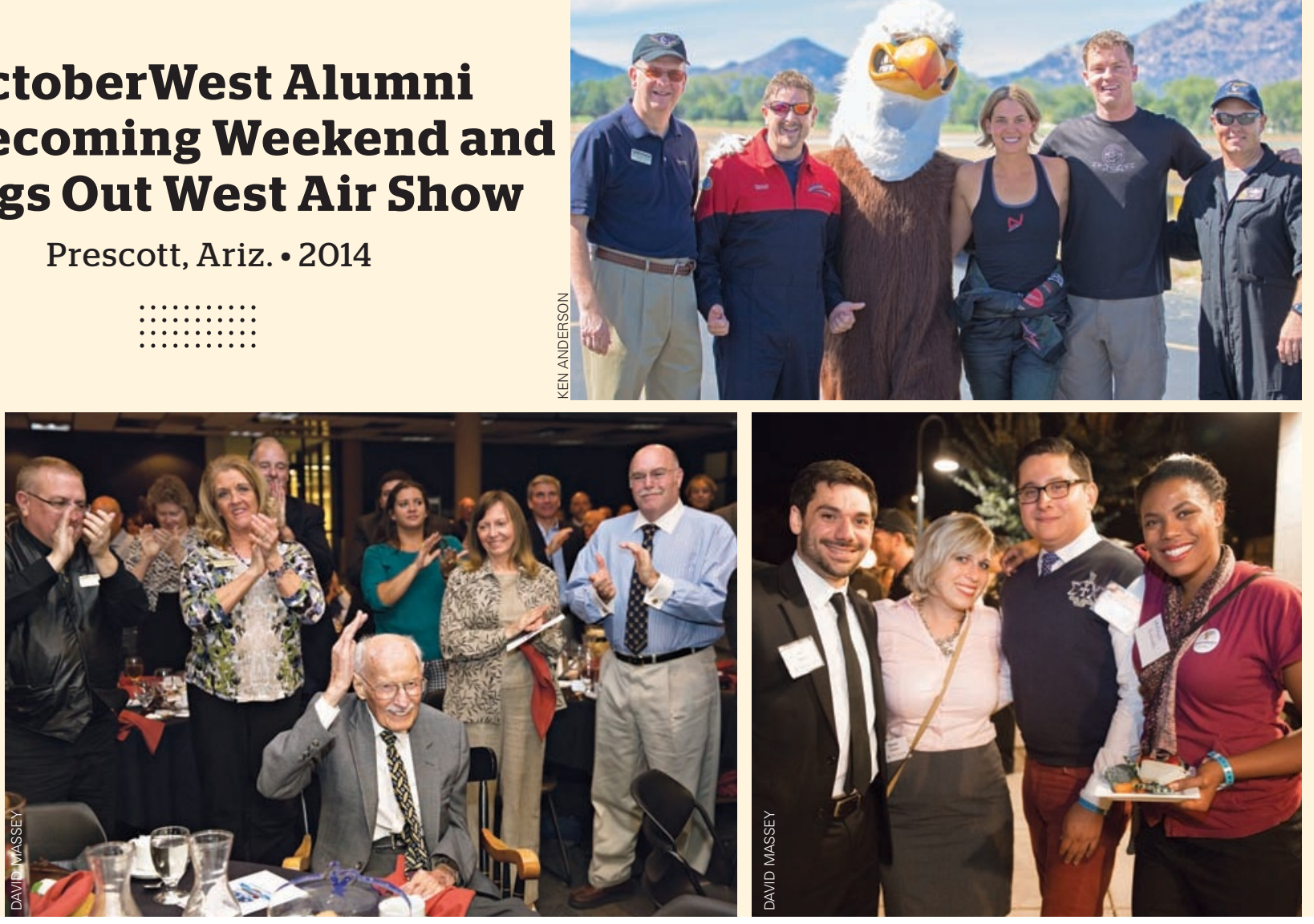

Alumni celebrate homecoming $<$

Alumni

Homecoming

Weekend and Wings \& Waves Air Show

Daytona Beach, Fla. 2014
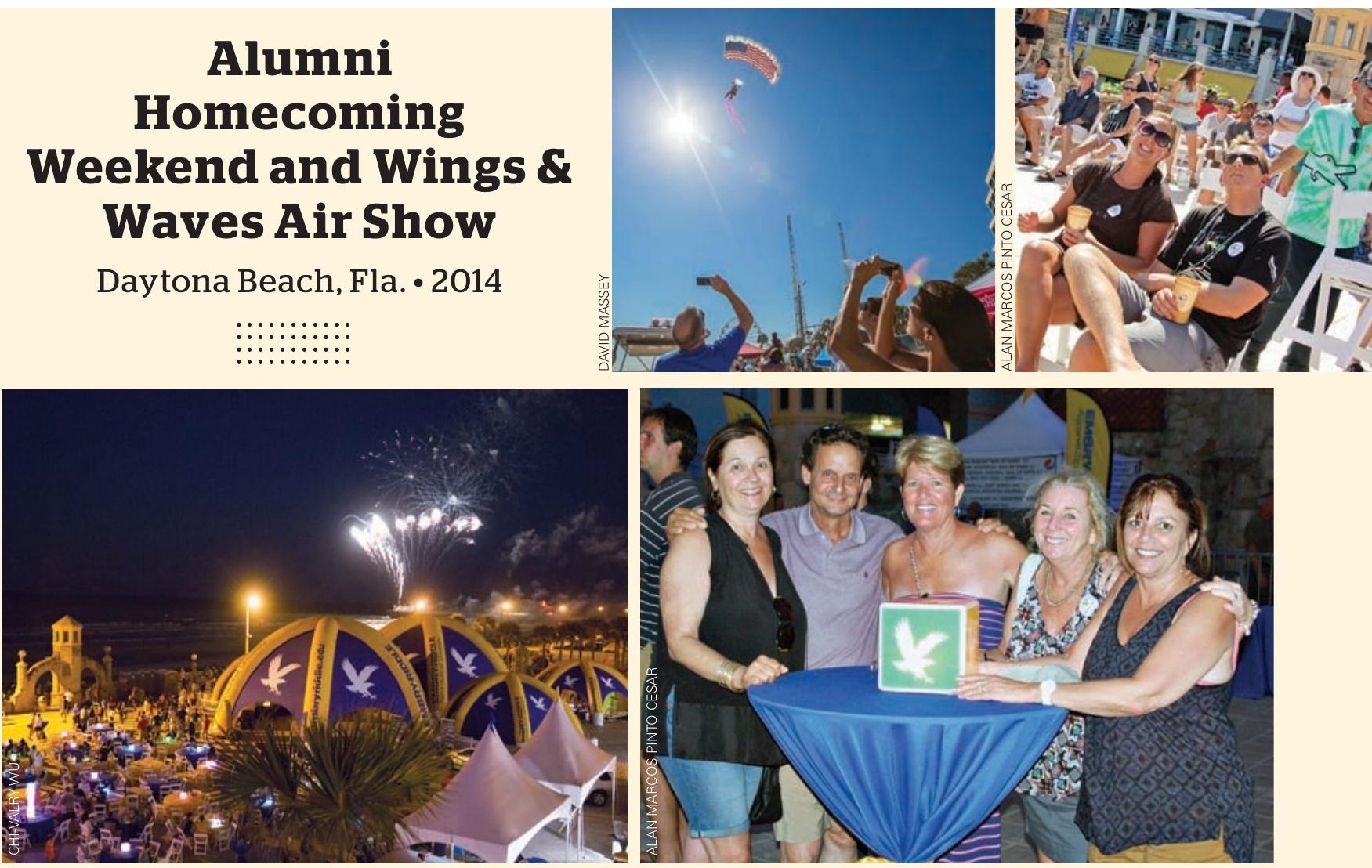


\section{Unique Connection}

\section{Aeronautical Engineering Class of 1984 celebrates its 30-year reunion at the Prescott Campus}

\section{BY SARA WITHROW AND EDMUND ODARTEY ('04, '10, DB)}

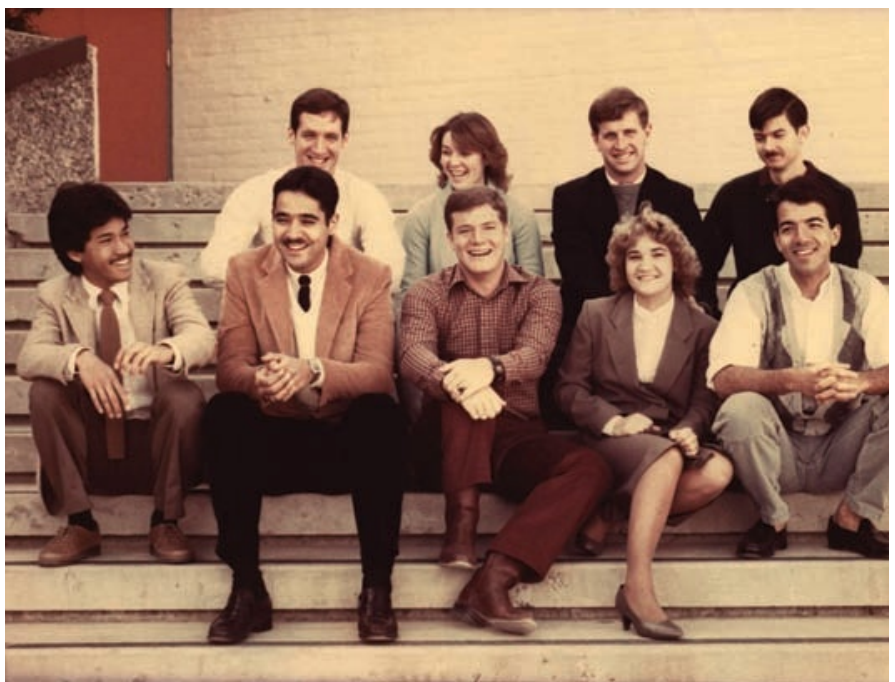

t was 1979 when the Embry-Riddle Board of Trustees proposed the then 1-year-old Prescott Campus add an Aeronautical Engineering ( $A E$ ) program. Fortunately, the campus had the ideal candidate to lead the program already employed as a flight instructor: Tracy Doryland, a Navy veteran with an M.S. in Aeronautical Engineering from the Naval Postgraduate School. After working feverishly over the summer to prepare, Doryland welcomed the program's first students in the fall of 1980.

Fast-forward four years. It's April 1984, and nine students are celebrating the completion of their bachelor's degrees-becoming the Prescott Campus's first-ever AE graduating class. Calling their Embry-Riddle experience "foundational," seven of these charter graduates haven't missed a 10-year reunion since that day, and 2014 was no exception. The group, which includes Vincent Chin, Jay "J.P." Morgan, Col. Ken Rosson, Cheryl (Mueller) Giuffre, Mark LaPole, Margaret "Peg" (Mcllvaine) Billson and Lt. Gen. Tom Trask, came together last fall at the annual OctoberWest Alumni Weekend to celebrate the 30th anniversary of their graduation.

"To get back together with this crowd is real special, because they're family and we all grew up together," says LaPole, director of Imaging at Ball Corporation. "And these old buildings, as much as they keep wanting to scrape them down, just like homes, they have spirits in them, and I feel it when I'm here."

"There is something magical about this campus," echoes Morgan, deputy program executive officer for acquisition for the Department of Defense in Fort Meade, Md. "Why return? Because it's tradition; it's about connections and family. I love these people; it's that simple."

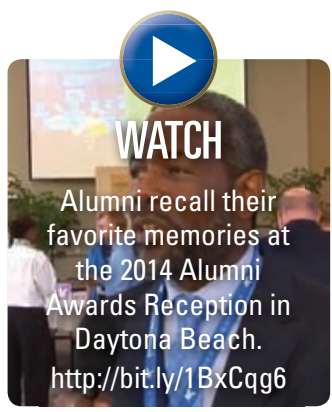

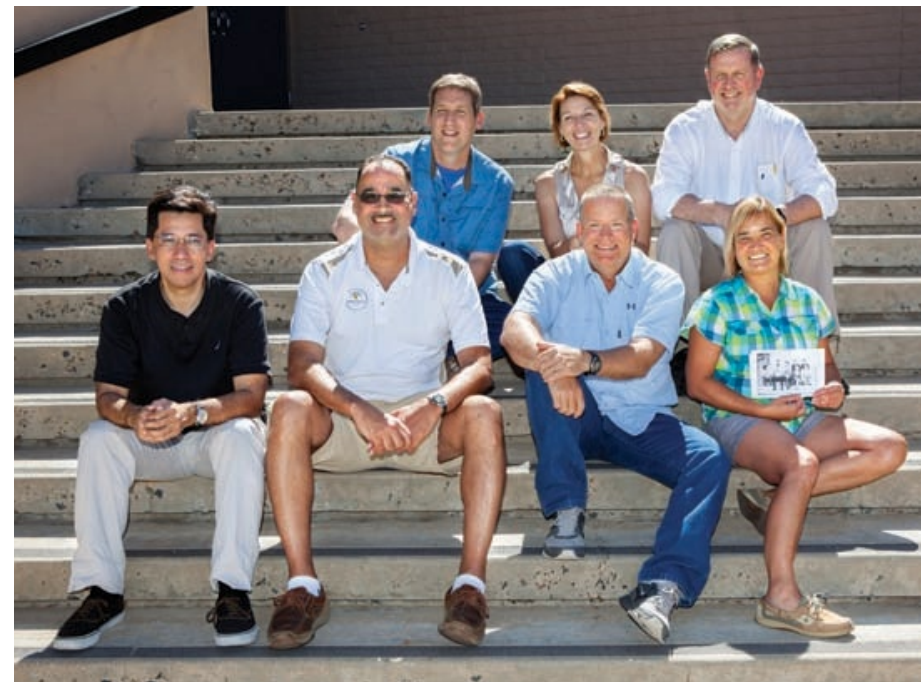

Left, the 1984 Class of Aeronautical Engineering at the Prescott Campus (April 1984), left to right, front: Vincent Chin, Jay 'J.P' Morgan, Ken Rosson, Cheryl (Mueller) Giuffre, Constantine Kioussis; back, Mark LaPole, Margaret 'Peg' (Mcllvaine) Billson, Tom Trask and Paul Anneler. Right, 30 years later (2014), assuming positions similar to their 1984 photo are, front: Chin, Morgan, Rosson, Giuffre; and back: LaPole, Billson and Trask.

In addition to staying connected with each other, the '84 AE Class at Prescott is a stalwart supporter of their alma mater. At their 20-year reunion the group contributed a $\$ 100,000$ class gift to name the wind tunnel laboratory in honor of their beloved professor Tracy Doryland. Doryland retired in 2005 and was named professor emeritus.

"Tracy Doryland is one special man to me," says Rosson, vice commander for the 162nd Wing of the Arizona Air National Guard. "My best memory of my time here is of the professors working with us, getting us through. That's the reason we graduated."

Trask, who is vice commander of Headquarters U.S. Special Operations Command in Washington, D.C., agrees. "It was all of us together, the faculty and us, trying to figure out the next step. I think that challenge is unique and one that most people don't get in their college experience."

"When I look back 30 years now, I'm honored by what we helped create," adds Giuffre, a senior engineer and structural analyst for The Boeing Company. "It was like this river, and we were all going along the same path. And, when we graduated, we all somehow positively influenced the world. That just doesn't happen at any university. There had to be something special to make that happen." 


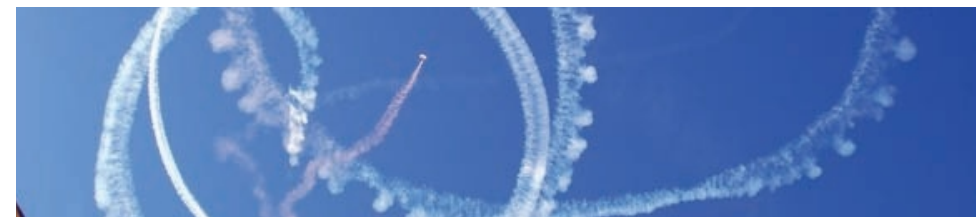

Save the Date

\section{OctoberWest Homecoming Weekend and Wings Out West Air Show}

\section{PRESCOTT, ARIZ.}

THURSDAY, OCT. 1 Industry/Career Expo eagleNIGHT
FRIDAY, OCT. 2

26th Annual Alumni Golf

Tournament

Alumni Awards
SATURDAY, OCT. 3

Wings Out West Air Show

Fly-in, Static Display and

Pancake Breakfast

Fireworks

\section{Alumni Homecoming Weekend and Fly-in DAYTONA BEACH, FLA.}

\author{
WEDNESDAY, OCT. 7 \\ Industry/Career Expo \\ THURSDAY, OCT. 8 \\ eagleNIGHT and \\ Alumni Awards
}

\author{
FRIDAY, OCT. 9 \\ Alumni Return \\ to Classes \\ Campus Tours \\ Hangar Party \\ Fly-in Arrivals
}

\section{CAREER CORNER}

\section{MARK YOUR CALENDAR 2015 Industry and Career Expos:}

\section{THURSDAY, OCT. 1}

Prescott, Ariz.

WEDNESDAY, OCT. 7

Daytona Beach, Fla.

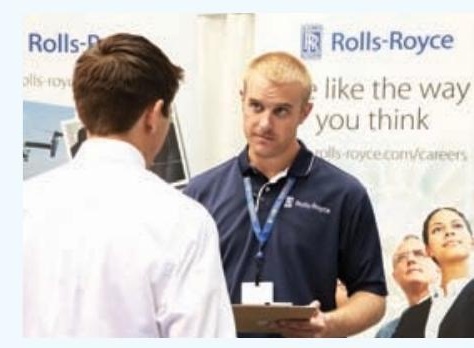

For additional information and job resources: careerservices.erau.edu.

\section{Lifelong Learning ERAU PROFESSIONAL EDUCATION COURSES}

Unmanned Aircraft Systems April 2-3, 2015,

San Diego, Calif.

\section{OSHA 30-Hour \& Aviation}

Ground Safety

April 13-17, 2015,

Daytona Beach, Fla.

\section{Aviation Safety Program \\ Management \\ April 20-24, 2015, \\ Daytona Beach, Fla.}

Aircraft Accident Investigation April 27-May 1, 2015,

Daytona Beach, Fla.

\section{Advanced Aircraft Accident} Investigation

May 4-8, 2015,

Prescott, Ariz.
Aviation Safety Management Systems May 12-14, 2015, Daytona Beach, Fla.

\section{Airport Wildlife Hazard}

Management June 3-5, 2015, Dallas, Texas

\section{A3IR Summer Research} Institute

June 22-26, 2015,

Prescott, Ariz.

\section{NextGen 101 Seminar}

June 23-24, 2015,

Washington, D.C.

To register and for additional information visit http://proed. erau.edu.

\section{Bvents on the panah}

For the most up-to-date list of events, visit alumni.erau.edu/ events.

APRIL 19-26

Sun 'n Fun 2015,

Lakeland, Fla.

MAY 2

Prescott Campus Commencement,

Prescott, Ariz.

Worldwide

Campus Commencement,

Daytona Beach, Fla.
MAY 11

Daytona Beach

Campus Commencement, Daytona Beach, Fla.

MAY 16

Worldwide

Campus Commencement,

Seeheim, Germany

MAY 31

Worldwide

Campus Commencement,

San Diego, Calif.
JUNE 6

Worldwide

Campus Commencement,

Pensacola, Fla.

JUNE 15-21

International Paris Air Show,

Paris, France

JULY 20-26

EAA AirVenture Oshkosh 2015,

Oshkosh, Wis.

SEPT. 5

Worldwide

Campus Commencement,

Ford Island (Oahu), Hawaii
SEPT. 12

Worldwide

Campus Commencement,

Seattle, Wash.

ост. 3

Worldwide

Campus Commencement,

Dallas, Texas

NOV. 17-19

National Business Aviation

Association Business Aviation Convention \& Exhibition,

Las Vegas, Nev. 


\section{CLASS NOTES}

To share your Class Notes with Lift and your fellow alumni, join Embry-Riddle's online community

at alumni.erau.edu/join today; or submit your announcements through email to eralumni@ erau.edu. For guidelines, visit alumni.erau.edu/ notes_guidelines.

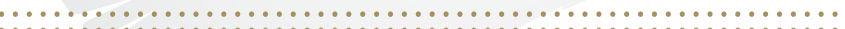

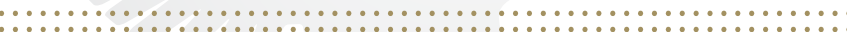

\section{Career News}

\section{0 s}

Robert Stambovsky ('72, DB; ' 85 , WW) retired from NASA's Armstrong Flight Research Center at Edwards Air Force Base in 1998. A Marine combat Vietnam veteran, he returned to active duty after $9 / 11$ with the Marine Air Reserve in 2001, and retired from active duty in 2004. He and his wife, Donna, reside in Lancaster, Calif. $\mathrm{He}$ is an active flight instructor, jet air show pilot, air show announcer, senior adjunct professor at Embry-Riddle and flight line coordinator for the Miramar Air Show.
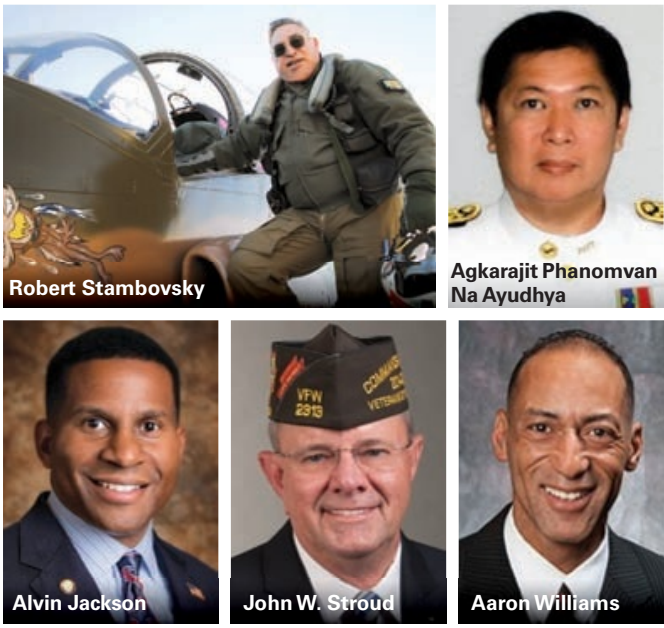

Retired U.S. Air Force Maj. Ralph 0. Irwin ('77, ' 87 , WW) retired for the second time in September 2012, after being recalled to active duty for two years as a pilot assigned to U.S. Air Force Special Operations Command at Hurlburt Field, Fla. His first retirement was nearly 20 years ago.

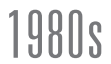

Agkarajit Phanomvan Na Ayudhya ('82, WW) was appointed Honorary Consul for the Republic of the Philippines in upper northern Thailand, based in the city of Chiangmai. Previously, he spent 26 years in various roles at Thai Airways International PCL. He encourages alumni visiting upper northern Thailand to contact him via Linkedln for advice and assistance.
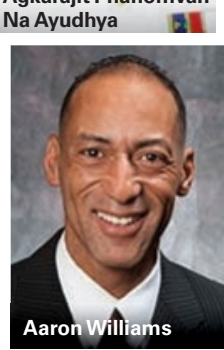

Armando Alvear ('83, WW) retired in 2012 as frontline manager from the Federal Aviation Administration (FAA) and lives in South Texas. Alvear was an air traffic controller for 37 years for the FAA, U.S. Air Force and Department of Defense. He taught at Del Mar College in Corpus Christi, Texas, and for Embry-Riddle's Worldwide Campus at Naval Air Station Kingsville and Naval Air Station Corpus Christi.

Bill Polise ('87, DB) is a captain for Delta Air Lines on the 737NG, based in New York. Hired by Delta in 1997, he was a flight engineer and first officer on the B-727 and flew 14 years on the 767ER as a first officer.

Polise retired in 2011 as a lieutenant colonel from the U.S. Air Force. He served eight years active duty as a C-141 pilot in the 6th Military Airlift Squadron, based at McGuire Air Force Base, N.J. In 1995, he joined the Air Force Reserve in the 76th Air Refueling Squadron. He lives in New Jersey with his wife, Pam, and has three children.

Kathi Durst ('88, WW) is now chief pilot for American Airlines at Dallas/Fort Worth International Airport. She is the first female pilot based at American's Dallas/Fort Worth hub to hold this position.

Jim Anderson ('89, PC) was elected treasurer of the Society of Aviation and Flight Educators Board of Directors. He is senior vice president of Starr Aviation, a global aviation insurance firm.
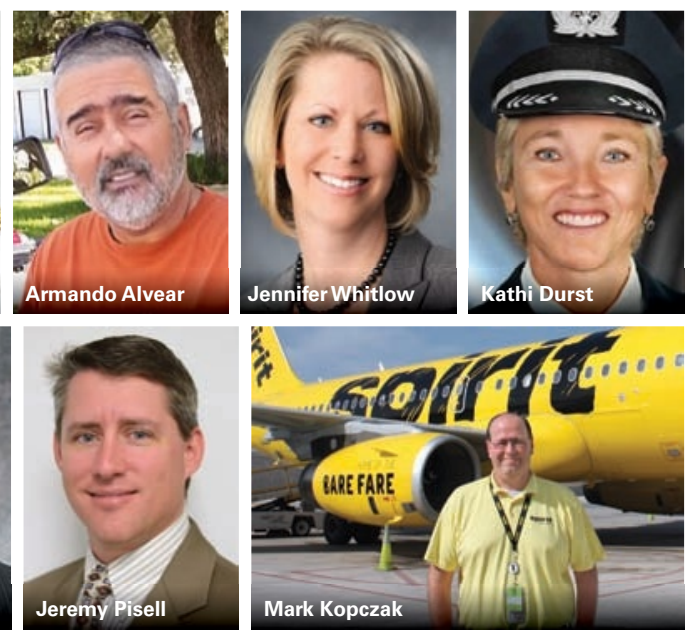

Hussain bin Ibrahim AI Hammadi ('89, DB) was appointed minister of education for the United Arab Emirates.

\section{0s}

John Cox $(' 90, P C)$ is the manager of Ernest A. Love Field, the City of Prescott's municipal airport.

Alvin Jackson ('90, DB) was elected by Republican delegates to fill a vacancy in the Utah State Senate representing District 14. Jackson is principal of his own consulting firm. He is also a member of the Embry-Riddle President's Advisory Board.

John W. Stroud ('90, WW) was elected senior vice commander-inchief of the Veterans of Foreign Wars (VFW) at the VFW's 114th National Convention in Louisville, Ky.

Aaron Williams ('92, WW) was named director of Webster University's Space Coast/Merritt Island, Fla. location.

Mark Kopczak ('93, DB) is vice president of network planning at Spirit Airlines in Miramar, Fla. He is pictured with one of Spirit's Airbus A319 aircraft.

Bongani Maseko ('93, DB) is managing director of the Airports Company South Africa.

Doug Taylor ('93, PC) was recently upgraded to Airbus 320 captain at Delta Air Lines.

Jeremy Pisell ('94, DB) was promoted to manager of FlightSafety International's Learning Center in Houston, Texas.

Jennifer Whitlow ('94, DB) is senio vice president of communications at Lockheed Martin.

\section{CAMPUS LEGEND \\ MC Miami Campus \\ DB Daytona Beach, Fla. \\ PC Prescott, Ariz. \\ WW Worldwide Campus \\ BFTS No. 5 British Flying Training School}



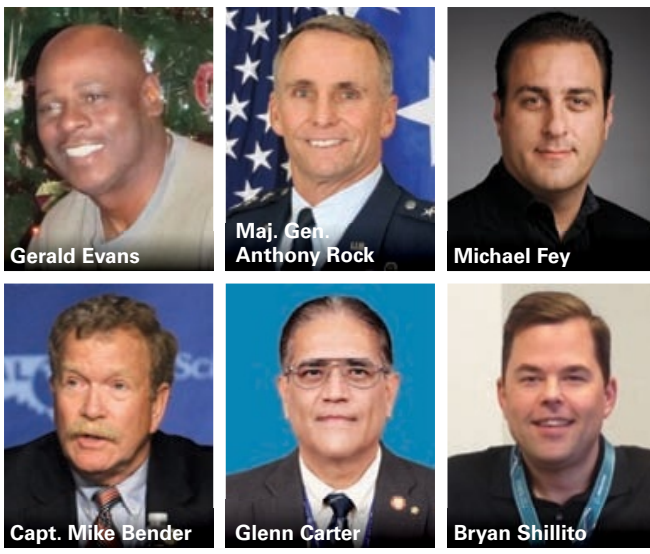

Maj. Gen. Anthony Rock ('95, WW) was promoted to three-star general in the U.S. Air Force on June 19, 2014.

Retired U.S. Air Force Col. M. Jay Mitchell (‘96, WW) was appointed secretary of the New Mexico Department of Homeland Security and Emergency Management.

Alison Smalling ('96, ‘98, DB), Embry-Riddle's sports information director at the Daytona Beach Campus, was named the 2013-14 Sun Conference Sports Information Director of the Year in the inaugural presentation for the award.

Retired Navy Intelligence Officer Tom Chapman ('97, WW) was named director of the Cyber Operations Group at EdgeWave.

Michael Fey ('97, DB) was appointed president and chief operating officer of Blue Coat Systems Inc.

Troy Kohler ('97, WW) is vice president of MacAulay-Brown Inc. He leads the company's operations and logistics division.

U.S. Air Force Capt. Matthew K. Morrison ('97, PC) was awarded the Distinguished Flying Cross with Combat "V" for outstanding heroism and selfless devotion to duty while in aerial flight as an F-16CJ pilot. On March 22, 2003, near Baghdad, Iraq, Morrison exhibited outstanding airmanship and dedication to his mission under extremely hazardous conditions.

Air Force Lt. Col. Mark Visco ('97, WW) retired from the Air Force on July 1, 2014. He served more than 12 years as an instructor-pilot. Most recently, he commanded the 512th
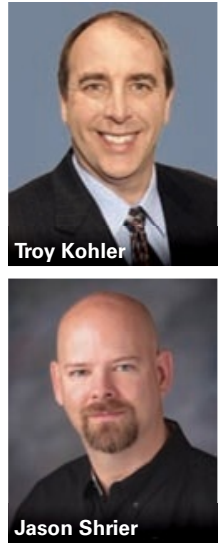

Jason Shrier ('99, DB) was promoted to general manager of Helicopter Specialties Inc. (HSI), in Janesville, Wis. He has been HSI director of maintenance since 2007.

James Sowell ('99, DB) is the CEO of Planetary Science Corporation, located in Titusville, Fla.

\section{0s}

Kim Ellis ('00, WW) is manager of Riverside Municipal Airport, operated by the City of Riverside, Calif.

Force Base.

Capt. Mike Bender ('98, WW), a FedEx Express employee, was presented the Air Line Pilots Association International's highest safety honor, the Air Safety Award. An Anchoragebased MD-11 pilot, he was commended for his dedication to investigating and preventing airline accidents.

Glenn Carter ('98, ‘06, DB) was named dean of the School of Aviation Science at Daniel Webster College in Nashua, N.H.

Natasha Parks ('98, DB) was awarded the NASA Exceptional Public Achievement Medal in August 2014, for her work on NASA systems development and vehicle assembly building operations.

Bryan Shillito (‘98, PC) was named managing director of safety programs for Alaska Air Group. He leads Air Group's cross-organizational safety programs.

Cmdr. Andrew Eriks ('99, WW) is commander of Coast Guard Air Station/ Sector Field Office Port Angeles.

Gerald Evans ('99, WW) is a supervisory immigration services officer with the U.S. Citizenship \& Immigration Services in Tampa, Fla. He is also an adjunct instructor for Everglades University. He and his wife, Jelena Evans, and three children reside in the Tampa area.

Capt. W. Patrick Gordon ('99, WW) was appointed acting president and CEO of Royal Jet, an Abu Dhabibased luxury flight services company. ('01, WW) took command of the Defense Logistics Agency-Central in a June 20, 2014, ceremony at MacDill Air Force Base, Fla.

Sean Rogers ('01, ‘02, DB) was named director of the Ph.D. Program in Management at New Mexico State University. Rogers is also an assistant professor of human resource management at the university.

Wess Gates ('02, DB) is the founder of Edtric Corporation, a development company focusing on unmanned aircraft systems and based in Signal Hill, Calif.

Kerry McGovern ('02, WW) is a regional sales manager for Securaplane Technologies in Miami, Fla.

Russell “Buck" Myers ('02, WW) was named avionics supervisor for the service department at Phoenix, Ariz.based Cutter Aviation.

Greg Richman ('02, DB) is president of the new private jet charter company Skyjet. He will lead Skyjet from the company's headquarters in New York City.

Branka Subotic ('02, DB) is the executive director of Borealis, the European alliance of air navigation service providers.

Lt. Col. Jon “Huggy" Huggins ('03, WW) retired from the U.S. Air Force
2,500 hours in the $U-2,3,900$ hours in the T-38 and 700 hours in the MC-12. He recently joined the Citation Jet Pilots Owner Pilot Association as its executive director.

Andrea (Stuart) Sossa ('03, DB) is the assistant branch manager and corporate underwriter at Phoenix Aviation Managers Inc., in Renton, Wash. In 2014, she was nominated by the president/CEO and selected by Munich Re to participate in the Munich Re Scholarship Programme. In June, she completed the three-month international insurance management program, held in Munich, Germany. Sossa has worked in the aviation insurance field for 10 years. She is married to fellow Embry-Riddle alumnus Juan Sossa ('04, DB), who is a first officer for Envoy Air (formally American Eagle). on Sept. 26, 2014. He amassed over
Col. William L. Thigpen ('03, WW) was named commander of the 316th Cavalry Brigade at Fort Benning, Ga.

Josh Hunter ('04, DB) was hired to launch the corporate flight department for a manufacturing company in Indianapolis, Ind.

Allison Odyssey ('04, DB) is now NewSpace Global's chief operating officer.

Rick Wielebski ('04, PC) is general manager of Landmark Aviation's Boeing Field/King County International Airport near Seattle, Wash.

Heidi Stenger ('05, WW) is the administrative officer at Dickinson Municipal Airport in Dickinson, N.D.

Rashaad Wilford ('05, '10, WW) is a mechanical engineering supervisor at General Atomics Aeronautical Systems Inc. in San Diego, Calif.

Jared Allison ('06, DB) and Ru Selvadurai ('08, DB) created WingStats LLC, a career tracking system for pilots.

Sulaiman Zainul Abidin ('07, DB) was appointed chief operating officer of Pioneer Aerodrome Services, which manages Myanmar's Yangon International Airport and Naypyitaw International Airport. 
David Hewitt ('07, WW) was named chairman of the Air Charter Safety Foundation.

Lt. Col. John "Slick" Baum ('99, ‘08, WW) is a former U.S. Air Force Thunderbird pilot (left wing, No. 2), performing for the 2009 and 2010 show seasons. Previously, he was an F-16 instructor at the Air Force Fighter Weapons School. He is presently stationed at the Pentagon.

Ryan Hartman ('09, WW) was named president and CEO of Insitu Inc., a wholly owned subsidiary of The Boeing Company. Hartman most recently served as senior vice president, Insitu Programs.

Chris S. Perry ('09, DB) was elected president and CEO of the Kentucky Association of Electric Cooperatives.

Maria Baugh-Horstman ('10, WW) an engineer for Barrios Technology, was honored with NASA's Silver Snoopy Award, recognizing her outstanding work in standardizing the Soyuz cargo return process.

Lisa Villegas ('10, DB) joined the CBS Channel 11 weather team in Dallas/Fort Worth. Previously, she was a meteorologist for KRGV in the Rio Grande Valley and KLFY in Lafayette, La.

Neil Brackin ('11, WW) is vice president of flight operations at Fargo Jet Center in Fargo, N.D. He also
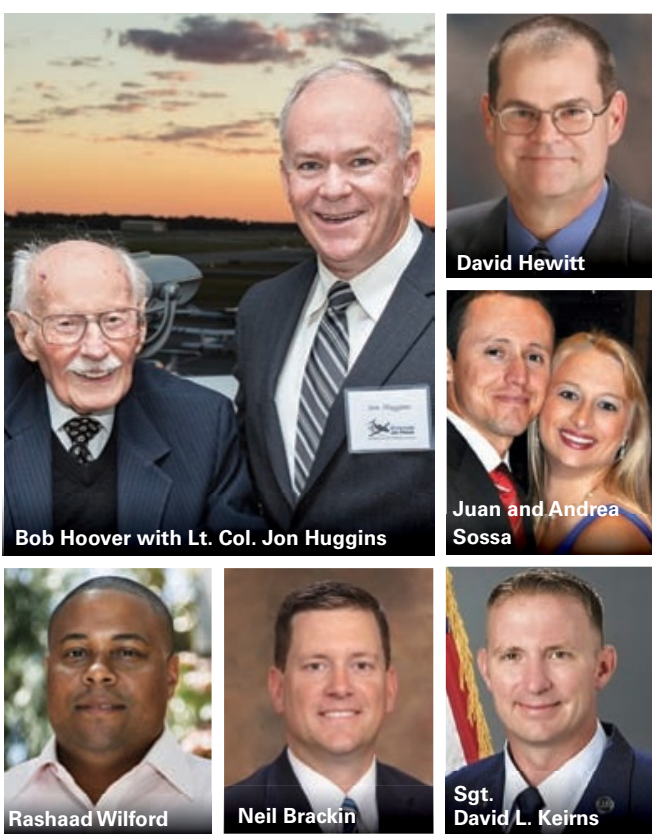
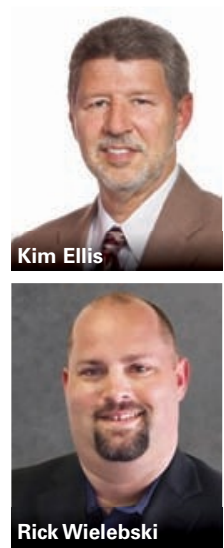

serves as interim general manager of Eden Prairie, Minn.-based Premier Jet Center. Brackin was formerly director of the General Mills flight department.

Carl Newman ('11, WW) is the CEO of the Jackson Municipal Airport Authority in Jackson, Miss.

Beau Tatsumura ('11, WW) was appointed director of line maintenance at Hawaiian Airlines.

Jeffrey Haas ('13, DB) is a technical support engineer for BellowsTech, an Ormond Beach, Fla.-based manufacturer.

Julia Bury ('14, DB) is a first officer at Cape Air in Hyannis, Mass.

Bill Highfill ('14, DB) joined Spirit Aeronautics in Columbus, Ohio, as director of maintenance.

Sgt. David L. Keirns ('14, WW) was selected as the 2014 Air Force Times Airman of the Year. He is the aircraft maintenance unit lead production superintendent at the 725th Air Mobility Squadron at Naval Station Rota, Spain.

Will Livsey ('14, WW) was hired by the Memphis-Shelby County Airport Authority as senior manager of air service research and development.

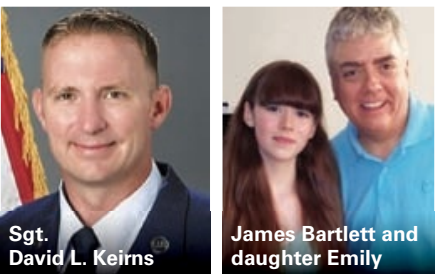

Justin D. Martin ('14, DB) is a general engineer at the NextGen NAS Lifecycle Integration Office. As a student, Martin was a volunteer at the NextGen Florida Test Bed at Embry-Riddle and president of the Daytona Beach Campus Student Alumni Association.

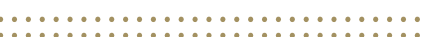
Family News

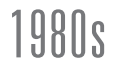

James "Jim" Bartlett ('82, DB) is a 767 First Officer at Delta Air Lines. His daughter, Emily, 14, recently started attending high school. They reside in New Hampshire.

2000 s

Gregory Migirditch Jr. ('03, ‘04, DB) and his wife, Kristy, welcomed a daughter, Samantha Avery, into the world on Dec. 20, 2013. Gregory works as an air traffic controller at the Memphis Air Route Traffic Control Center. The family resides in Collierville, Tenn.

Mikhael Ponso ('03, ‘'12, DB) and Roberta Borges Vieira celebrated the birth of their son, Ben Vieira Ponso, on July 8, 2014. Ponso is a former chief test pilot, instructor pilot/check pilot at Embry-Riddle and associate director of Embry-Riddle's Eagle Flight Research Center. Since November 2012, he has been a first officer for Spirit Airlines, based in Fort Lauderdale, Fla.

Jonathan Rupprecht ('09, WW) and his wife, Ashley, welcomed their first child, Anna Grace, on March 28, 2014. Jonathan is a criminal defense attorney at the Law Offices of Roger P. Foley. The family resides in Palm Beach, Fla.

Chris Carta ('13, DB) and his wife, Tori, welcomed their daughter, Camdyn, on July 25, 2014. Chris is manager of admissions and marketing for Embry-Riddle's Aviation Maintenance Science department at the Daytona Beach Campus and Tori is the business manager for the Athletics department at the Daytona Beach Campus.

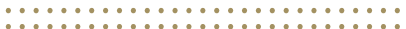

\section{Marriages/} Engagements

\section{0s}

Michael Duailibi (‘05,'13, WW) married Jennifer Boyd on May 31, 2014. Duailibi is an A32 captain for Spirit Airlines and Boyd is a flight attendant for Spirit Airlines.

Christopher Schreiber ('08, DB) married Angeline Ranieri ('10, DB) on June 11, 2014, in Key West, Fla. Christopher is an air traffic controller at the Fort Lauderdale-Hollywood International Airport and Angeline works for Saab Sensis as a strategy and product management specialist.

Drew Casey ('09, DB) married Jie Fan on Sept. 14, 2013, in Betterton, Md. Drew and Jie live in Beijing, China, where Drew teaches English and composition at Renmin University. The wedding party included alumni Scott Leonard ('08, DB), in a Flash Gordon T-shirt, and Thomas Dalton ('08, DB), in a Superman T-shirt.

Brian Walters ('09, PC) is a lieutenant in the U.S. Navy and a MH-60R helicopter pilot. He and Kathleen Franco were married on Nov. 30, 2013; they live in San Diego, Calif.

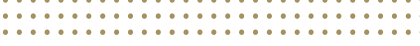

\section{Other}

Ralph Kling ('43, MC) met Prescott Campus flight instructors Jeff Premo ('07, PC) and Kyle Buse ('12, WW) at AirShow San Diego at Gillespie Field, held June 7-8, 2014. After graduating from Embry-Riddle, Kling flew a P-47 Thunderbolt fighter during World War II. On his 68th mission, he was shot down on Sept. 21, 1944, and sent to POW Camp Stalag Luft III. 
Alumni and Sigma Chi brothers Steve Whitlock ('77, DB) and wife Carol, David Fraser ('77, DB), Tony Kralich ('77, DB), Greg Maltese ('77, DB), John “Jay" Smullen III ('77, DB), Phil Wheeler ('84, DB) and wife Greta, Mike Rossbach ('76, DB, Non-degree), Don Haddox Jr. ('76, '78, DB) and wife Melanie, and Kathy Ford, wife of the late Morris Ford ('75, DB), raised $\$ 17,000$ for Ride Allegheny, an annual bicycle ride that supports the needs of wounded American service members at Walter Reed National Military Medical Center in Bethesda, Md. Email steve@whitlockonline. org to participate in the 2015 ride. For more: http://bit.ly/1yrgTWG

Cmdr. Joseph McMonigle ('93, DB) and Cmdr. Brian Ferguson ('93, DB) stand in front of a Navy F-5 Tiger adversary aircraft from Fighter Squadron Composite 111 (VFC-111) in Key West, Fla. (see photo). McMonigle and Ferguson were commanding officers of Navy adversary squadrons during the same time period. McMonigle commanded VFC-111 in Key West, while Ferguson commanded VFC-13 in Fallon, Nev.
Embry-Riddle's Daytona Beach Campus Athletics program inducted seven new members into its Hall of Fame on Feb. 6. The honorees are: Embry-Riddle Trustee Emeritus Jay Adams Jr. (HonDoc '08), distinguished member category; former baseball coaches Greg and Todd Guilliams, coaches category; former men's basketball tri-captains, AKA "The Foundation," Owen Busch ('94, DB), Tom Fagley ('94, DB) and Jeff Moore ('94, DB), athlete category; and women's track and field and cross country standout Beth McCubbin ('09, DB), athlete category.

Jonathan Faught ('07, DB), Will Brazelton ('05, DB; '11, WW), Josh Odom ('05, DB) and Scott North pose at the Grand Canyon in October (see photo). The four friends embarked on a cross-country motorcycle adventure on 0ct. 4 to remember their friend and fellow alumnus Benjamin Glattstein, who died in an aircraft accident in 2010. An Embry-Riddle scholarship fund has been organized in his memory, The Ben Glattstein Upset Recovery Training Scholarship. givingto.erau. edu/glattstein/
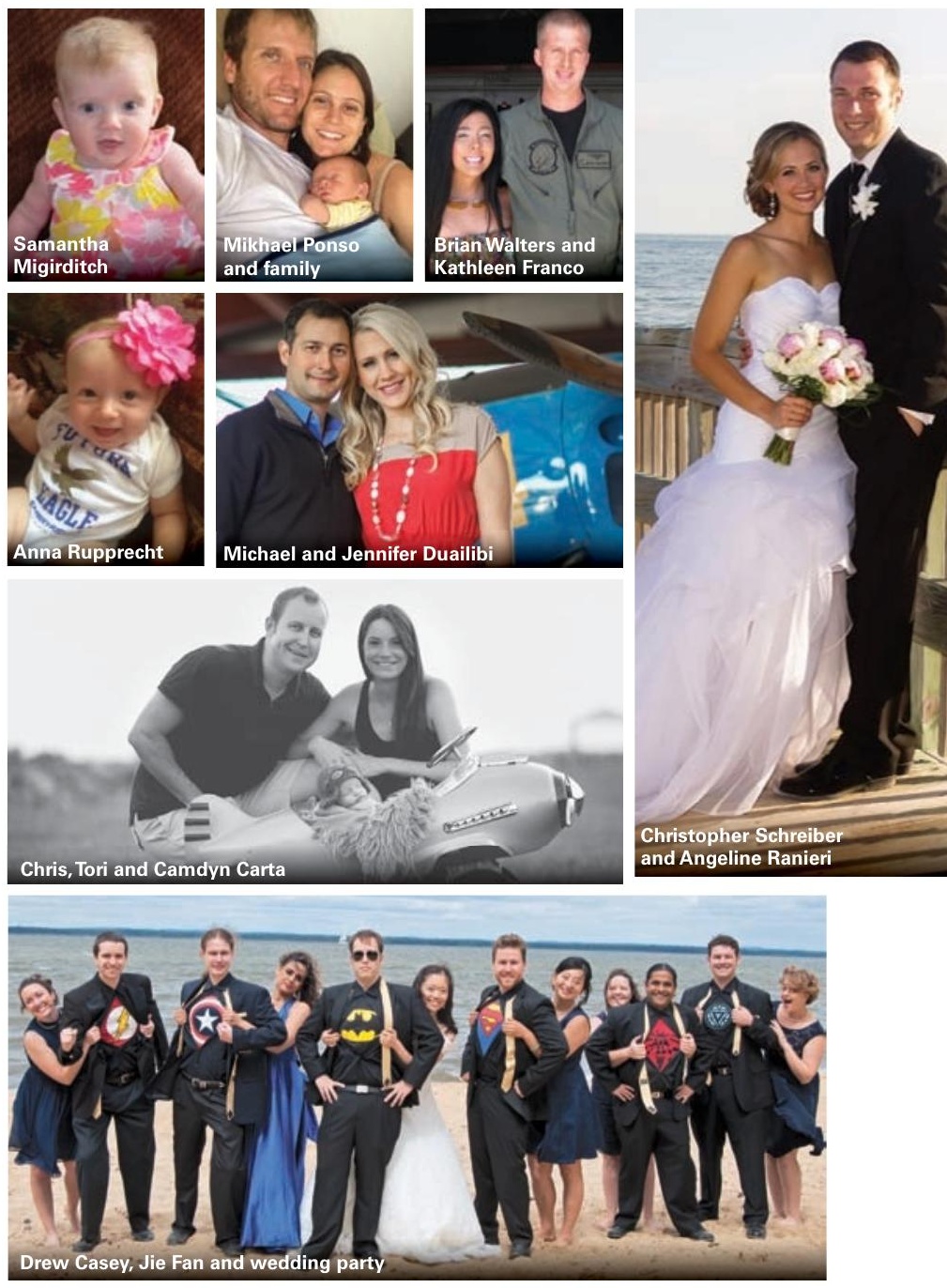

\section{EAGLE AUTHORS}

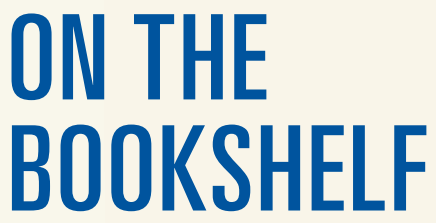

Stephen Carbone ('97, '01, WW) authored his first novel, Jet Blast, published September 2014 by Tate Publishing. Carbone is a former aircraft maintenance investigator for major commercial accidents for the National Transportation Safety Board and a current airworthiness technical specialist for the Federal Aviation Administration. “Though Jet Blast is fictional, it is based on my experiences in accident investigation and techniques the NTSB uses during its investigations," he says.

Hassan M. Eltaher ('80, DB) authored Aviation \& Maritime Security Intelligence, published by E \& W Communications in 2012.

Retired U.S. Air Force Col. Robert Harvey ('80, '81, '87, WW) authored The Whole Truth, The Tainted Prosecution of an American Fighter Pilot, published in 2013; and Cocoa, Florida, A History, published in 2014.
Retired U.S. Air Force Lt. Col. Brian Duddy ('83, DB) authored Invasion Stripes: The Wartime Diary of Captain Robert Uhrig, USAAF and the Dawn of American Military Airlift, published in 2013

Frank J. Donohue Jr. ('85, DB) authored School and Schooled: A Flight Plan for Life and an All-American Story of Hard Work and Success, published August 2014. Donohue is a FedEx A300 captain. He and his wife, Bernadette, reside in Virginia Beach, Va., and have two grown children.

Margo Kelly ('91, PC) authored Who R U Really?, published by Merit Press in September 2014, a novel based on events experienced by Kelly's daughter, who narrowly escaped being abducted by a man she met in an online roleplaying game. Kelly is a veteran public speaker and resides in Idaho.

Thomas Field, assistant professor of global studies at Embry-Riddle's Prescott Campus, authored From Development to Dictatorship: Bolivia and the Alliance for Progress in the Kennedy Era, published in June 2014, by Cornell University Press. 

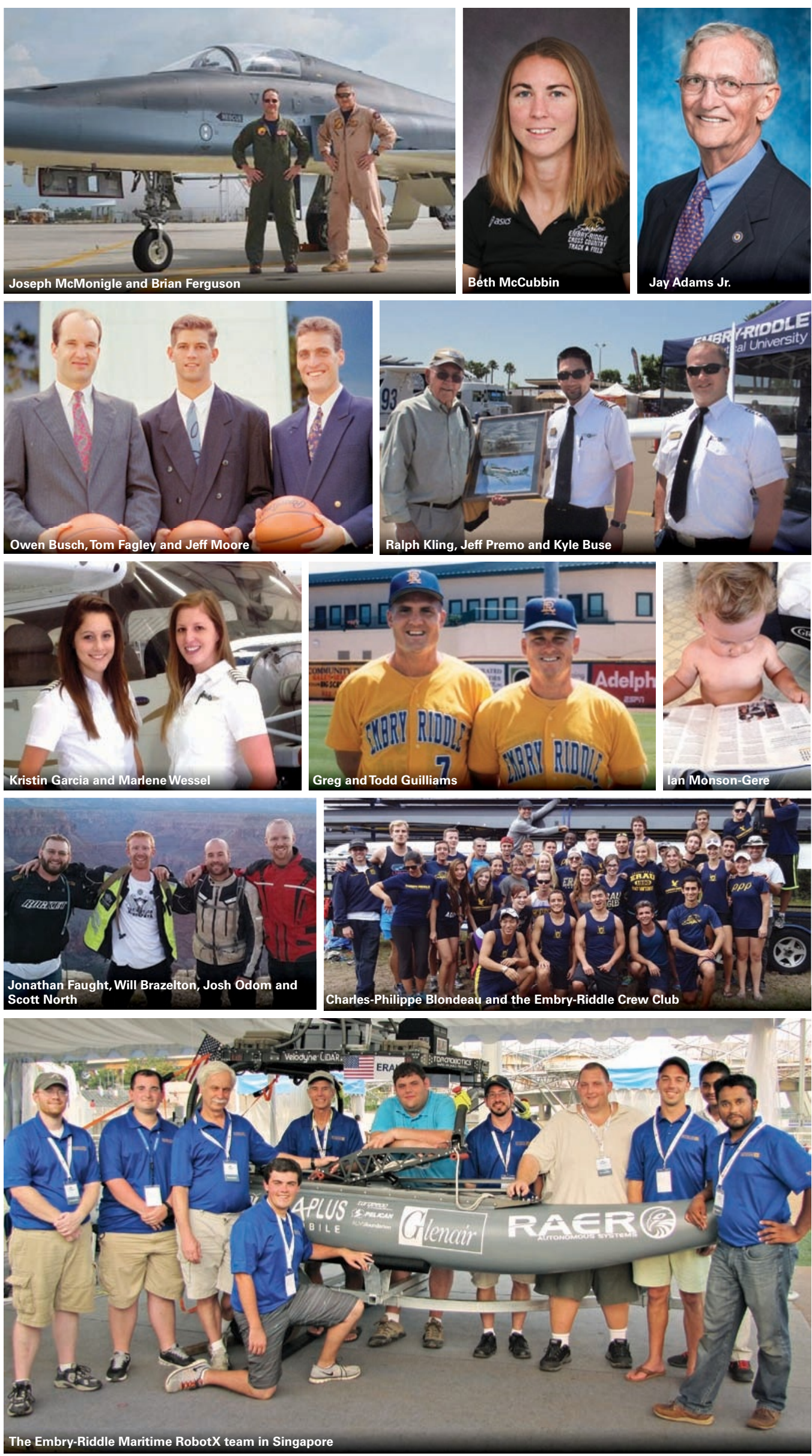

Valdeta Mehanja ('13, DB) and

Nancy Snyder, a student at the

Daytona Beach Campus, took first place in the collegiate division at the women's Air Race Classic, held June 16-21, 2014. The duo also finished second overall out of 50 teams. The Prescott team, Marlene Wessel ('13, PC), an Embry-Riddle Worldwide Campus student, and Kristin Garcia ('14, PC), placed fourth in the collegiate category and 10th overall.

Charles-Philippe Blondeau ('14, DB) earned a B.S. in Mechanical Engineering and is now pursuing an M.S. in Mechanical Engineering at Embry-Riddle. Blondeau is also president of the Daytona Beach Campus's Crew Club, which competes at the varsity level against other universities. The club celebrates the 25th anniversary of its founding this spring. Alumni interested in getting involved with the Crew Club and/or helping it celebrate its 25th anniversary should email blondeac@my.erau.edu.

Hitesh Patel ('12, '14, DB),

Christopher Hockley ('06, '10, DB), Christopher Kennedy ('12, '14, DB), Tim Zuercher ('12, DB) and student Gene Gamble were members of an Embry-Riddle Daytona Beach Campus team that finished fourth overall at the Maritime RobotX Challenge, held in Singapore in October. The event was co-sponsored by the Office of Naval Research and the Association for Unmanned Vehicle Systems International Foundation. EmbryRiddle was one of only three U.S. schools selected to participate in the contest. The team received $\$ 11,000$ in prize money, and multiple awards and accolades.

Ian, the son of Mecca Monson-

Gere, associate campus director of the Worldwide Campus in Kaneohe, Hawaii, peruses the class notes in the Fall 2014 issue of Embry-Riddle's Lift magazine. 
Mark A. Goldstein ('86, WW) Oct. 31, 2014

\section{In Memoriam}

1940s

Sir Jack Hayward ('41, BFTS) Jan. 13, 2015

Ernest A. Sinnes ('43, MC)

March 14, 2014

David J. Smith ('45, BFTS)

Jan. 2, 2015

1950s

Robert W. Anderson ('51, MC)

Sept. 10, 2014

James L. Kington ('58, MC)

Feb. 25, 2014

Louis F. Boynton (‘59, MC)

April 14, 2014

19f0s

Antonio Bolet ('62, MC)

April 30, 2014

Raymond S. Cayuso ('67, DB)

July 21, 2014

$1970 \mathrm{~s}$

Andrew Potaczala ('70, DB)

Nov. 11, 2014

Ned R. Akens ('72, DB)

Oct. 29, 2014

Capt. Richard J. Henkel ('78, WW) June 14,2014

1980s

Retired U.S. Air Force Maj.

Roy L. Jones ('83, PC)

Oct. 24, 2014

Howard Z. Nuzum Jr. ('83, DB)

July 31, 2014

Retired U.S. Air Force Lt. Col. Samuel S. Mumaw ('85, WW) Aug. 25, 2014

Sidney M. Allagood ('89, WW)

Jan. 12, 2014

Michael R. Stizza ('89, DB)

Sept. 26, 2014

1990s

Bradley D. Cook ('90, DB)

May 29, 2014

Paul C. Ekholm ('90, WW)

May 24, 2013

Gerald K. Carman ('93, WW)

Aug. 7, 2014

John E. Luke ('94, DB)

Aug. 14, 2014

Gale E. Reining ('94, WW)

June 12, 2014

2000/s

Marianne Postell ('00, WW)

Nov. 14, 2013

Charles P. Cash ('02, WW)

Tony J. Diotalevi ('02, WW) Oct. 15, 2013

Paul D. Toft ('02, WW)

July 31,2013

Gerald M. Fleming ('03, WW)

June 3, 2014

Philip R. Jacobs ('05, WW)

Nov. 08, 2014

Heather N. Bain ('06, PC)

Dec. 2, 2014

Richard D. French ('07, WW) March 23, 2014

Adedoyin E.B. Adewumi

('10, '14, DB)

Dec. 21, 2014

Rommel C. Beckles ('11, DB)

Aug. 5, 2014
April 26, 2014 elor's degree in aeronautical science.
Constance D. Hunter

BOARD OF VISITORS MEMBER; LEGACY SOCIETY DONOR

FEB. 23, 2014

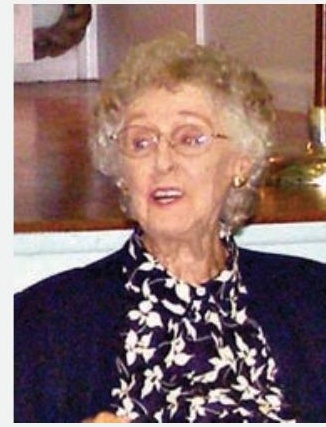

A former member of Embry-Riddle's Board of Visitors at the Daytona Beach Campus and Legacy Society donor, Constance D. Hunter was a dedicated supporter of Embry-Riddle and its mission.

"She believed in Embry-Riddle very strongly," says Bob Rockett, dean emeritus, who retired in 2010 after more than 35 years at the university and personally knew Constance. "She loved what Embry-Riddle stood for."

Serving on the Board of Visitors from 2002-2011, Constance was fond of Embry-Riddle's traditional and conservative values, its strong emphasis on education and the fact that the university valued women students, says Rockett. A young woman in England during WWII, she also appreciated that the university trained many British pilots for the war effort.

Constance established a scholarship for women in her name and another scholarship that honors the memory of her husband, Paul B. Hunter, who passed away in 1980. The Constance D. Hunter Scholarship for Women, established in 2006, benefits Daytona Beach Campus female students with financial need; while the Paul Benwood Hunter Memorial Scholarship, created in 1987, is awarded to engineering students, regardless of gender.

"Mr. Hunter was an intellectual property attorney and he very much believed in technology and moving the world forward, and Mrs. Hunter was a very independent, strong-willed woman who emphatically believed in education for women," says Pam Clifton, one of the directors of the Hunter Foundation, whose office is in Ormond Beach, Fla.

Upon her death, Constance bequeathed a $\$ 1$ million gift to the two endowed scholarships at Embry-Riddle. "The scholarships are a wonderful testament to her life," says Chris Lambert, Embry-Riddle's senior executive director of development. "Generations of students will be touched by her generosity and her passion for education."

\section{Katherine C. Schwikert Waidmann ('02, DB)}

NOV. 25,2014

Former women's soccer scholar-athlete Katherine "Kate" C. (Schwikert) Waidmann ('02, DB) of Delray Beach, Fla., didn't give up without a fight. For two and a half years she valiantly fought invasive cancer. "She was an inspiring model of a loyal, positive, and determined person facing her challenges. Kate was the ultimate fighter," says Embry-Riddle Head Women's Soccer Coach Samantha Bohon.

Waidmann played for the Eagles and Head Coach Dan Blank in 1999 and 2000. A fixture in the Eagles' starting lineup for two seasons, she earned first team All-Conference honors in 2000 and graduated from Embry-Riddle's Daytona Beach Campus with a bach-

Originally from Troy, Mich., Waidmann was diagnosed with cancer in September of 2012. Despite aggressive surgery and treatment, the cancer returned. She died at the age of 35

"We are heartbroken with Kate's passing, but I'm confident her legacy with ERAU women's soccer will live on," says Bohon.

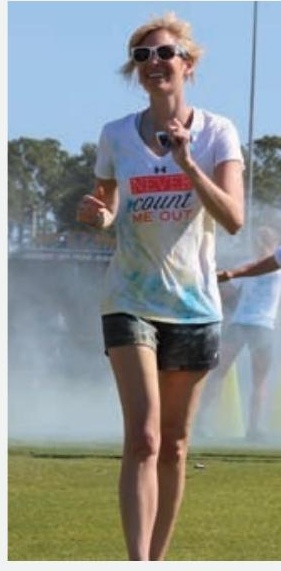

LIFT $\approx$ SPRING 2015 ๓ ALUMNI.ERAU.EDU 


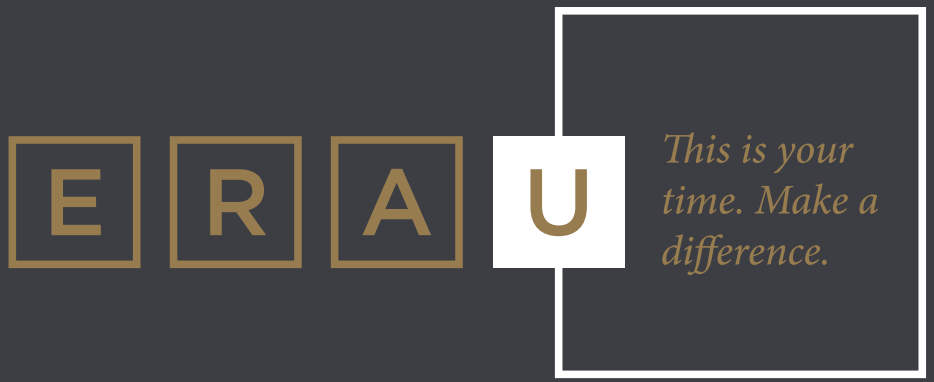

Whichever Embry-Riddle era you hail from, you are part of something very special.

We call it the ERA of $\mathbf{U}$.

This is your time to make a difference.

Please make a gift today and help us launch the next great era of achievement at Embry-Riddle.

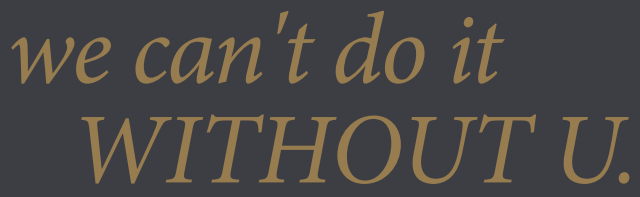

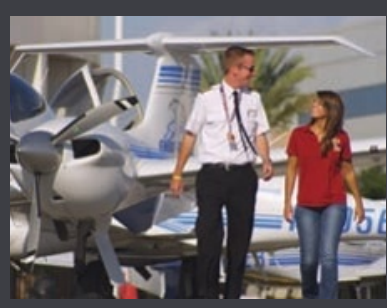
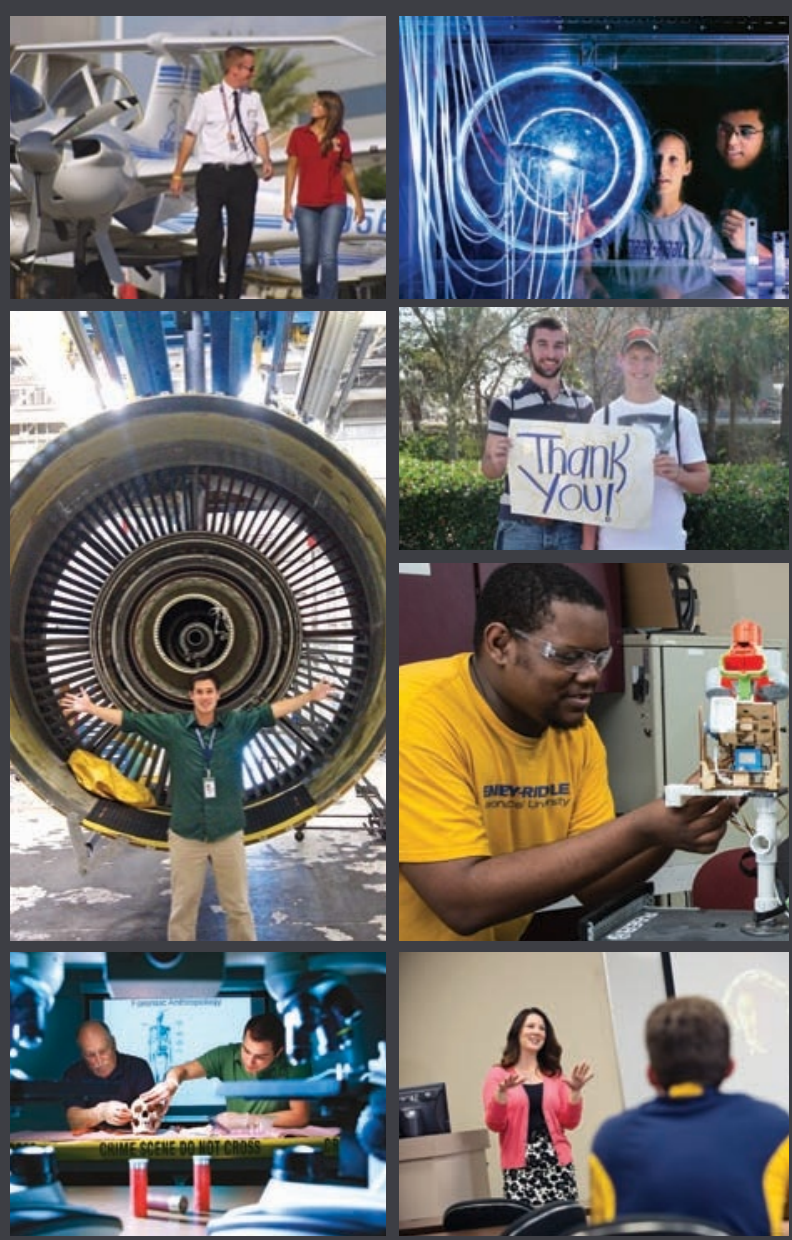

\section{回度回

